\title{
Species of Boletaceae (Boletales, Basidiomycota) with ornamented spores from temperate forests at the state of Oaxaca, Mexico
}

\author{
Ayala-Vásquez $\mathbf{O}^{\mathbf{1}, 2}$, Valenzuela $\mathbf{R}^{\mathbf{1}}$, Aguirre-Acosta $\mathbf{E}^{3}$, Raymundo $\mathbf{T}^{\mathbf{1}}$, García- \\ Jiménez $\mathbf{J}^{2 *}$
}

${ }^{1}$ Instituto Politécnico Nacional, Escuela Nacional de Ciencias Biológicas. Departamento de Botánica. Esq. Carpio. Plan de Ayala s/n Col. Casco de Santo Tomás, Miguel Hidalgo, zipe code 11340 Mexico, D. F.

${ }^{2}$ Tecnológico Nacional de México. Instituto Tecnológico de Cd. Victoria, Boulevard Emilio Portes Gil \#1301 Pte. A.P. 175 C.P. 87010 Cd. Victoria, Tamaulipas, México.

${ }^{3}$ Universidad Nacional Autónoma de México. Ciudad Universitaria, C.P. 70-233,04510 Cd de Mexico.

Correspondence author: jgarjim@yahoo.com.mx

Ayala-Vásquez O, Valenzuela R, Aguirre-Acosta E, Raymundo T, García-Jiménez J 2018 Species of Boletaceae (Boletales, Basidiomycota) with ornamented spores from temperate forests at the state of Oaxaca, Mexico. Studies in Fungi 3(1), 271-292, Doi 10.5943/sif/3/1/28

\begin{abstract}
Ten species of Boletaceae with ornamented basidiospores are described and illustrated from temperate forests in the state of Oaxaca, Mexico. Boletellus ananiceps is recorded for the first time in Mexico, and Austroboletus gracilis, Boletellus flocculosipes, B. chrysenteroides, $B$. pseudochrysenteroides and Heimioporus ivoryi are first records from Oaxaca. While Aureoboletus russellii, B. coccineus, $H$. betula, Strobilomyces confusus only increase distribution in Oaxaca state. All species are described and illustrated and identification keys for the described genera are provided. The studied specimens were deposited in the national herbaria ENCB, ITCV and MEXU-UNAM.
\end{abstract}

Key words - Boletes - new records - Scanning electron microscopy (SEM) - taxonomy

\section{Introduction}

Boletaceae Chevall. is characterized by pileate-stipitated fleshy fungi with poroid hymenia, rarely lamellate (Phylloporus Quél.), globose, subhypogeous or hypogeous (Singer 1945, Binder \& Hibbett 2006, Wu et al. 2014, 2016). Despite Most genera of Boletaceae have smooth spores but some genera also have ornamented spores such as longitudinally or transversally striate

(Boletellus Murrill), shallow pitted (Borofutus Hosen \& Zhu L. Yang), pitted-alveolate, perforated (Heimioporus E. Horak), verrucose or reticulated (Strobilomyces Berk), bascillate (Phylloporus and Xerocomus Quél.), as in Aureoboletus Pouzar, Austroboletus (Corner) Wolfe and (Singer 1945 1986, Grand \& Moore 1971, Heinemann \& Goossens-Fontana 1954, Pegler \& Young 1981, Singer et al. 1991, Horak 2004, Neves et al 2012, Hosen \& Li 2017, Zeng et al. 2013, Wu et al. 2014, 2016). Boletes are common in template forest forming ectomycorrhizal associations with Abies, Alnus, Arbutus, Actostaphyllos, Betula, Fagus, Pinus, Quercus (Binder \& Hibbett 2006, Tedersoo et al. 2010, García Jiménez et al. 2014). Oak forests have a high degree of endemisms of Boletaceae (Mueller \& Halling 1995, Halling 1997). 
Though the Oaxaca state has a high fungal diversity (García-Mendoza et al. 2004), few studies in Boletaceae have been carried out. There are 146 registered species of Boletaceae in Mexico (Singer et al. 1990, 1991, 1992, García Jiménez 1999, García \& Garza Ocañas 2001), and only 18 species have been reported from Oaxaca (Heim \& Perreau 1964, Welden \& Guzmán 1978, Singer 1991, 1992, Garibay-Orijel et al. 2009). Some of the species described are important from an economic, edible and ecological point of view, since they are part of people's diet at the Sierra Norte, Mixteca and Valles Centrales (Garibay-Orijel et al. 2009, Jiménez Ruiz et al. 2013).

A striking feature of the topography of Oaxaca's territory is the massive and complex mountain formation located on its northern part. These mountains, collectively known as Northern Oaxaca Range (Sierra Norte de Oaxaca), actually form part of the Sierra Madre del Sur Physiographic Province, an extensive mountain complex that occupies much of southern Mexico (Ferrusquía-Villafranca 1993, Centeno-García 2004). In these Sierras are the temperate forests as Oak forest, cloud forest and boreal forest at altitudes of 1500 to $3720 \mathrm{~m}$, with at diverse vegetation (Rzedowski 1978). Mainly Quercus, since Oaxaca is the state with greater diversity this genus (Valencia 2004). several species of Pinus (Paray 1951, other genera such as Abies, Alnus, Arbutus, Carpinus, Liquidambar and Pseudotsuga.

\section{Materials \& methods}

The exploration was carried out in the state of Oaxaca, Mexico (Fig. 1); specimens were collected in temperate forest during the rainy season (i.e. from June to December) in the period of 2014-2017. Sample preservation was made according with (Cifuentes et al. 1986, Lodge et al. 2004). Color description was based on Kornerup \& Wanscher (1978). Hand-cut sections were mounted in $\mathrm{KOH} 5 \%$; Melzer's reagent was used for amyloid reactions and Congo red for staining the tissues. They include 30 measurements per structure according to Singer et al. (1992), García Jiménez (1999). The spores were studied using a scanning electron microscope (SEM) Zeiss DSM 950. Specialized literature was consulted (Singer 1945, 1947, 1955, 1983, 1986, 1970, Thiers 1963, Snell \& Dick 1970, Smith \& Thiers 1971, Wolfe 1979, García \& Castillo 1981, González-Velázquez \& Valenzuela 1993, García Jiménez 1999, Ortiz-Santana et al. 2007). Specimens were deposited at herbariums of Escuela Nacional de Ciencias Biológicas of Instituto Politécnico Nacional (ENCBIPN) and Instituto Tecnológico de Ciudad Victoria (ITCV), and at the Instituto de Biología of Universidad Nacional Autónoma de México (MEXU).

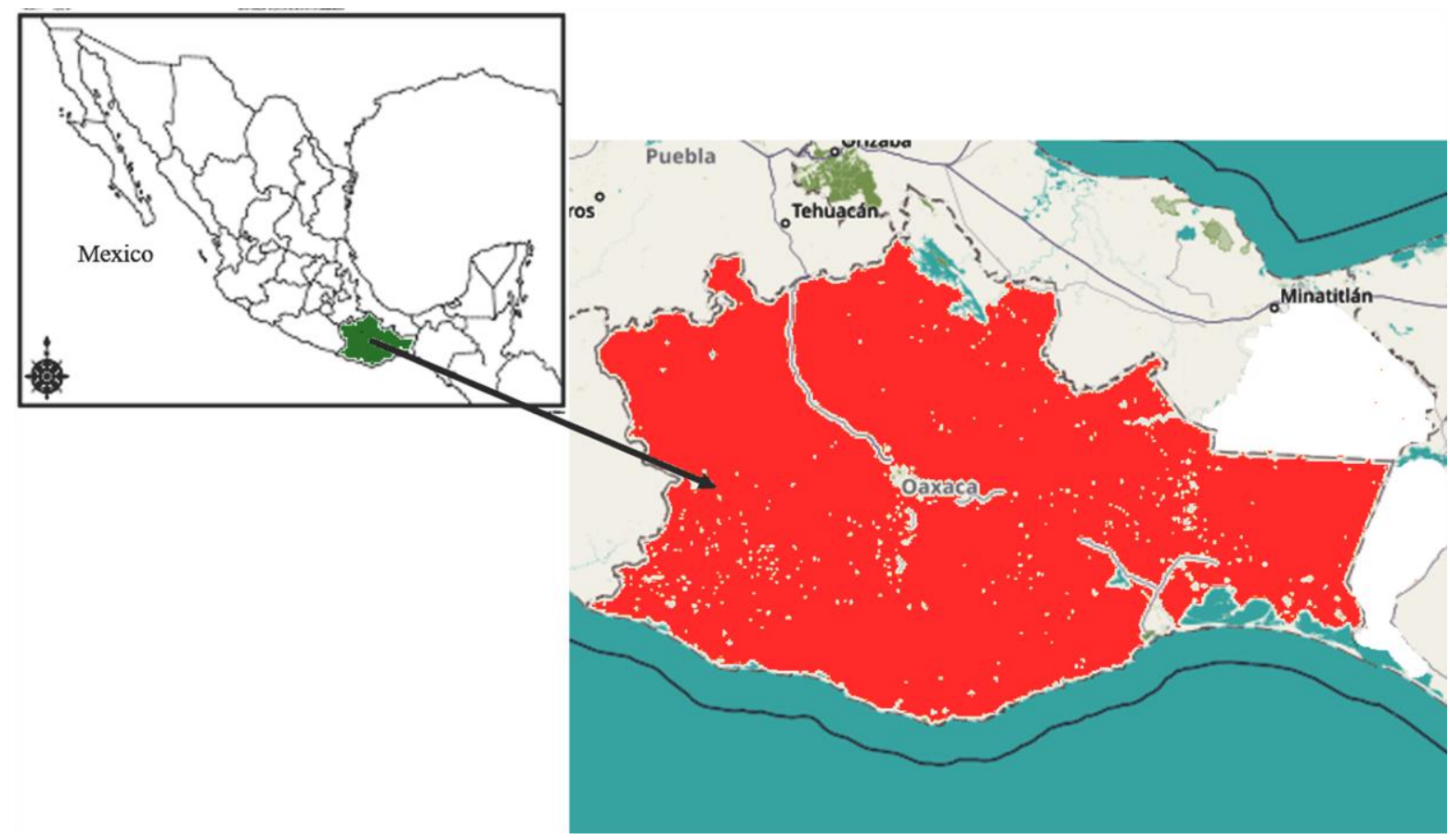

Fig. 1 - Oaxaca State of Mexico, sampling location. 


\section{Results}

Forty-five specimens of Boletaceae were collected from 12 localities at the state of Oaxaca, Mexico and 10 species were described. Boletellus ananiceps is hereby recorded for the first time from Mexico. Austroboletus gracilis, Boletellus chrysenteroides, $B$. flocculosipes, $B$. pseudochrysenteroides and Heimioporus ivoryi are new records for Oaxaca. Photographs (Figs 214), descriptions, discussions and a key for the species are presented.

\section{Key to species}

1a. Basidiomata with dark colors, hymenophore grayish to blackish or pinkish ..................2

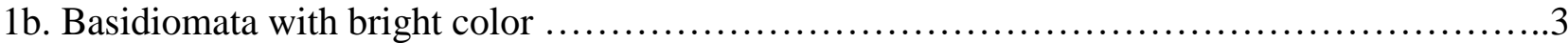

2a. Hymenophore grayish to blackish, verrucose basidiospores ..............Strobilomyces confusus

2 b. Hymenophore pinkish-brown or violaceus, pitted basidiospores ...........Austroboletus gracilis

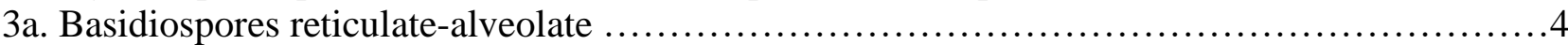

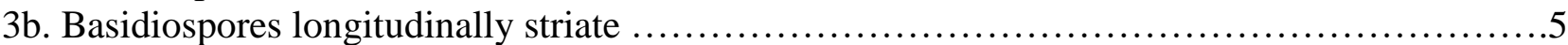

4a. Pileus viscid, smooth, orange-yellow or red ............................Heimioporus betula

4b. Pileus dry, tomentose, pink, red ................................................. ivoryi

5a. Stipe reticulate-alveolate ........................................Aureoboletus russellii

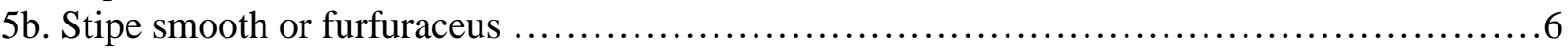

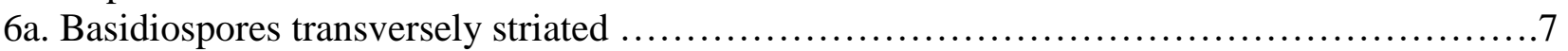

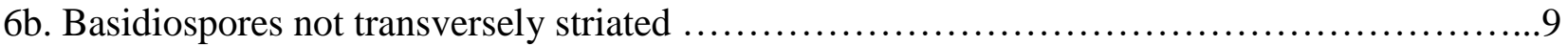

7a. Pileus dark brown ...............................................

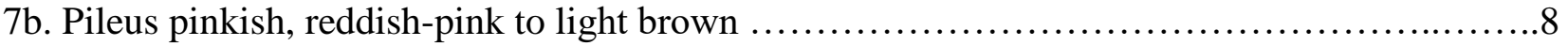

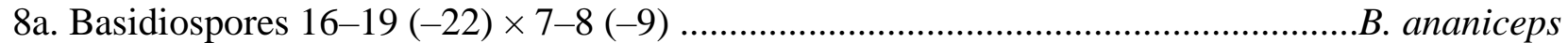

8b. Basidiospores 13.6-15.7 (-17.6) × 4.8-6 (-7.2) .............................. coccineus

9a. Pileus dark pink and dark red .......................................................... pseudochrysenteroides

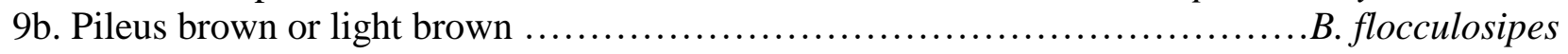

Aureoboletus russellii (Frost) G. Wu \& Zhu L. Yang, Fungal Diversity 81: 59 (2016)

Figs $2 \mathrm{~A}-\mathrm{H}, 4 \mathrm{~A}-\mathrm{B}$

三Boletellus russellii (Frost) E.-J. Gilbert, Les Livres du Mycologue Tome I-IV, Tom. III: Les Bolets: 107 (1931)

三Ceriomyces russellii (Frost) Murrill, Mycologia 1(4): 144 (1909)

三Frostiella russellii (Frost) Murrill, Contr. Herb. Univ. Fla. Agr. Exp. Stat. Gainesville: Jan. 5 1942: 6 (1942)

三Suillus russellii (Frost) Kuntze, Revis. gen. pl. (Leipzig) 3(2): 536 (1898)

Pileus 25-60 mm diameter, convex to plane-convex, reddish brown (8C7, 10D8) with yellowish (5A6) background, dry, subtomentose, rimose-areolate, with velar remnants projecting from the margin. Free hymenophore with a depression at the apex of the stipe, pores angular, 0.4$0.8 \mathrm{~mm}$ diameter, olive yellow (30A8), tubes 10-15 mm long, concolorous with the pores. Stipe clavate at the apex, 80-160 $\times 9-12 \mathrm{~mm}$ long, $12-20 \mathrm{~mm}$ at the base, somewhat curved towards the base, reticulate to alveolate surface, concolored to the pileus. Context 5-10 mm thick, yellowish (3A5), turns pink to pale red (12A5), the stipe of context reddish brown (8C7, 10D7), when bruised. Basal mycelium pale yellow.

Chemical reaction: When applying $\mathrm{KOH}$, the surface of the pileus and hymenophore they become reddish-brown; the context and stipe turn olive-brown.

Basidiospores 12.5-16(-19.2) × 8-8.8(-9.6) $\mu \mathrm{m},(\mathrm{Q}=2.1, \mathrm{~N}=30)$, ellipsoid, cylindrical, with longitudinal striate, complete and short, thick and conspicuous, brown-orange in $\mathrm{KOH}$ and Melzer's solution. Basidia 32-40 × 10.4-15.2 $\mu \mathrm{m}$, clavate, four-spored, with light brown content in $\mathrm{KOH}$, thin-walled, Pleurocystidia 66.5-76.8 $\times 15.2-24.7 \mu \mathrm{m}$, fusoid-ventricose, with a median neck, with brown content in Meltzer, thin-walled, hyaline in $\mathrm{KOH}$. Cheilocystidia 30-52 $\times 11.2-$ $13.6 \mu \mathrm{m}$, clavate-mucronate to fusoid-ampullaceous, thin-walled, hyaline to pale brown in $\mathrm{KOH}$. 
Hymenophoral trama boletoid; hyphae cylindrical, 3.2-6, $\mu \mathrm{m}$ wide, thin-walls, hyaline in $\mathrm{KOH}$, yellow in Melzer solution. Pileipellis $210-300 \mu \mathrm{m}$ wide, with palisade trichodermium with terminal cells28-92 × 5.6-14.4 $\mu \mathrm{m}$, cylindrical, clavate, rounded apex, hyaline in $\mathrm{KOH}$. Stipitipellis 120$180 \mu \mathrm{m}$ thick, Caulocystidia 40-69 × 7.2-12.8 $\mu \mathrm{m}$, fusoid-ventricose with long neck, hyaline in $\mathrm{KOH}$, with content, with some caulobasidia $32-39.2 \times 10.4-15.2 \mu \mathrm{m}$, broadly clavate, hyaline in $\mathrm{KOH}$, two-spored. Clamp connections absent.

Habitat - Solitary or scattered under $Q$. scytophylla and $Q$. urbanii in oak forest, cloud forest and pine-oak forest, during June to September.

Edibility - Quality edible.

Known distribution - In United States (Singer 1945, 1947), in Mexico (García-Jiménez 1999, González-Velázquez \& Valenzuela 1993).

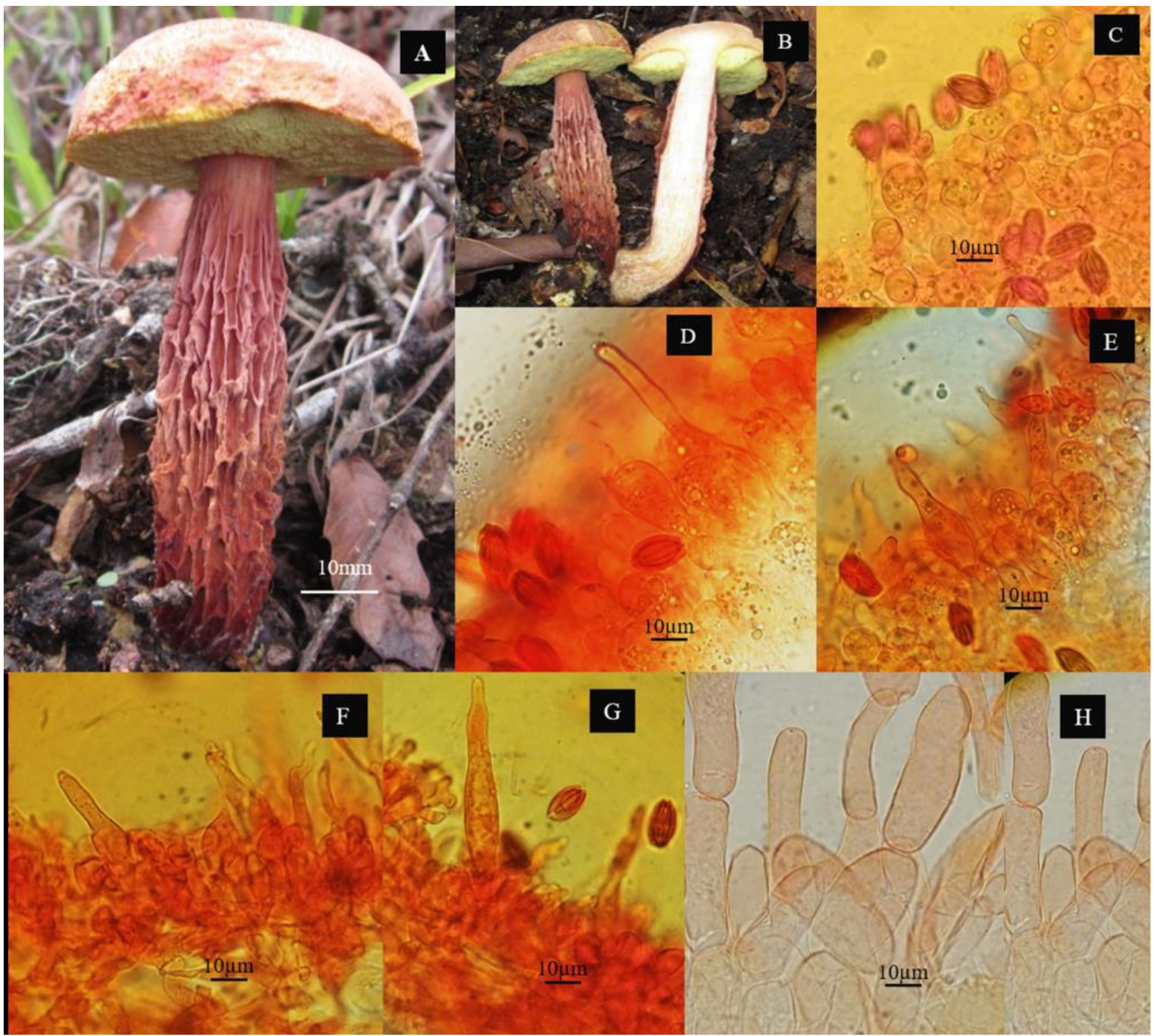

Fig. 2 - Aureoboletus russellii (ITCV-665). A-B Fresh basidiomata in the field. C Basidia. D Pleurocystidia. E Cheilocistydia. G-H Caulocystidia. 8 Pileipellis.

Examined materials-MEXICO, OAXACA, District Zacatepec Mixe, municipality Mixistlán de la Reforma, Santa María Mixistlán, 7 June 2014, Ayala-Vásquez 41 (ENCB-ITCV), District Zacatepec Mixe, municipality Mixistlán de la Reforma, Santa María Mixistlán 5 August 2015, Ayala-Vásquez 639, 640 (ENCB, ITCV), District Zacatepec Mixe, Municipality de Mixistlán de la Reforma, Santa María Mixistlán 7 July 2016, Ayala-Vásquez 710 (ITCV), District Zacatepec Mixe, municipality de San Pedro y San Pablo Ayutla, 2 July 2016, Ayala-Vásquez 665 (ITCV), District Zacatepec Mixe, Municipality Mixistlán de la Reforma, Santa María Mixistlán, 6 June 2017, 
Ayala-Vásquez 664 (MEXU-UNAM), District Ixtlán, municipality Santiago Laxopa, 1 June 2017, J. García-Jiménez, Ayala-Vásquez 21475 (ITCV).

Notes - Aureoboletus russellii is distinguished by the tomentose and dry to sub-viscid pileus, appendiculate margin and reticulate-honeycombed stipe, longitudinally striated spores, somewhat anastomosing. The studied material agrees with those described by (Singer 1945, Snell \& Dick 1970, González-Velázquez et al. 1993, García-Jiménez 1999).

Austroboletus gracilis (Peck) Wolfe, Bibl. Mycol. 69: 69(1979).

Figs 3A-H, 4C-D

三Boletus gracilis var. laevipes Peck, Ann. Rep. N.Y. St. Mus. nat. Hist. 38: 110 (1885)

三Suillus gracilis (Peck) Kuntze, Revis. gen. pl. (Leipzig) 3(2): 535 (1898)

Pileus 40-70 mm diameter, convex with young to plane-convex in the maturity; brown (6E8) to yellowish brown (5D5), grayish-brown (8D3), surface smooth, moist, somewhat cracked, bordered with white background at maturity; with entire margin. Hymenophore poroid, subadnate to depressed around the stipe, pores angular to irregular, 0.4-1 mm diameter, white to pink (13A3), pink-purple (14A4) or brown in maturity, tubes 15-20 mm long, concolorous with the pores. Stipe 60-70 $\times 10 \mathrm{~mm}$, cylindrical, tapering at apex, concolorous with the pileus, sometimes paler, surface furfuraceous to squamulose or slightly reticulated, with white base. Context 7-9 mm thick, white or pink (13A2), when exposed turns brown-violet (9B3), in the stipe invariable when expose. Mild to slightly acid flavor, odorless. Spore print pink-brown.

Chemical reactions. The $\mathrm{KOH}$ on the surface of the pileus turns it dark brown, the context is negative.

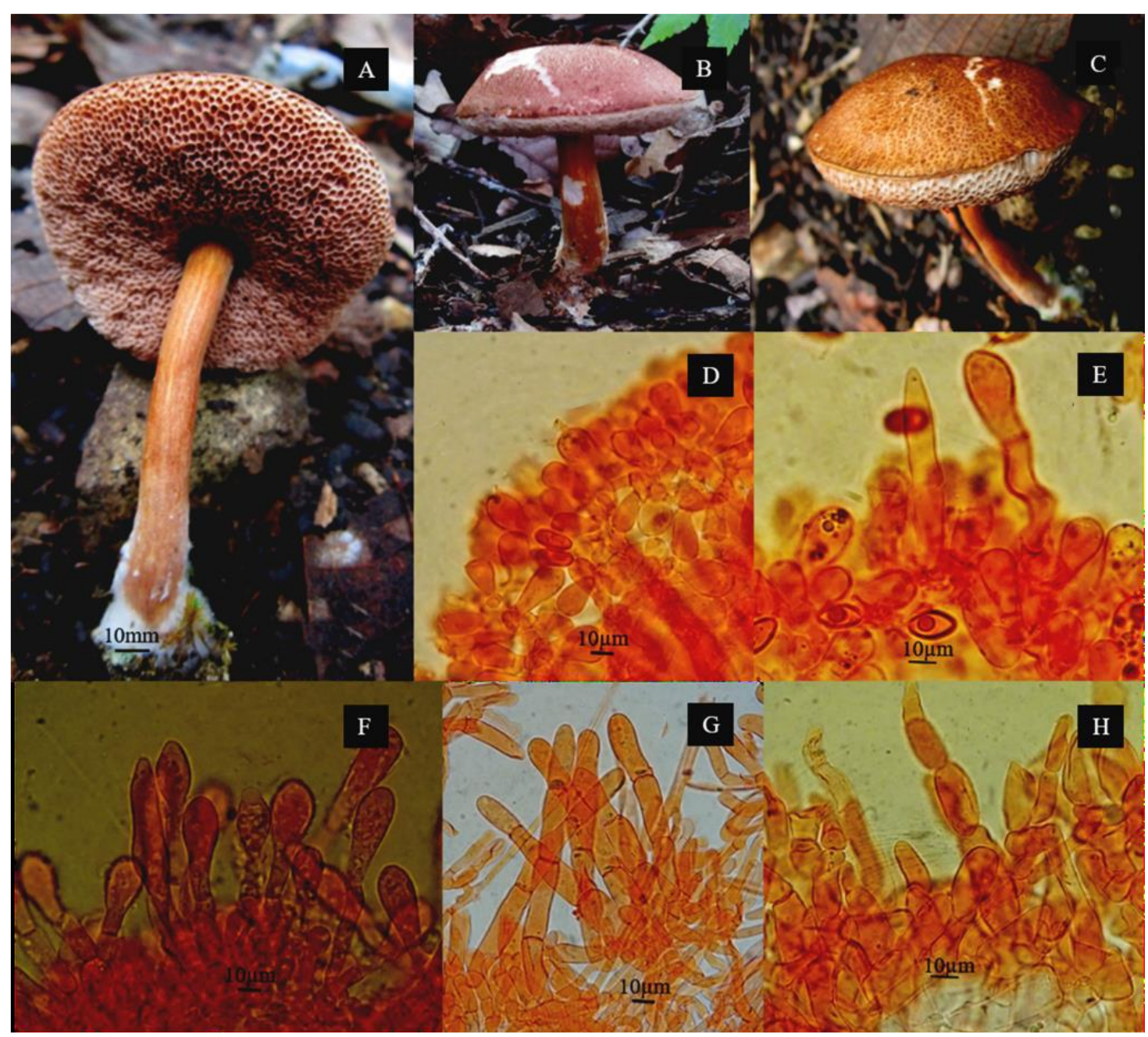

Fig. 3 - Austroboletus gracilis (ITCV-649, ITCV-1160). A-C Fresh basidiomata in the field. D Basidia. E Pleurocystidia. F Cheilocystidia. G Caulocystidia. H Pileipellis. 
Basidiospores $10-14.4 \times 5-8 \mu \mathrm{m}$, with a $(\mathrm{Q}=2.3, \mathrm{~N}=30)$, elliptical to ovate, inequilateral, with visible suprahilar depression, and pitted ornamentation, brown color in $\mathrm{KOH}$, yellow in Melzer solution. Basidia 27-34 × 7-15.2 $\mu \mathrm{m}$, clavate, four-spored, rarely two-spored, with esterigmata 2-4 $\times$ 0.5-1 $\mu \mathrm{m}$, thin-walled, hyaline in $\mathrm{KOH}$, yellow in Melzer solution. Pleurocystidia $28-53 \times 6.4-11 \mu \mathrm{m}$, fusoid-cylindrical to fusoid-ventricose, septate with content, hyaline in $\mathrm{KOH}$, yellow in Melzer solution, thin-walled. Cheilocystidia 25-65 × 6.4-11 $\mu \mathrm{m}$, subclavate, cylindrical with septa, hyaline in $\mathrm{KOH}$, yellow in Melzer solution, thin-walled. Hymenophoral trama boletoid; hyphae subcylindrical to cylindrical, 2-6 $\mu \mathrm{m}$ wide, thick-walls, hyaline in $\mathrm{KOH}$, yellow in Melzer solution. Pileipellis 100-110 $\mu \mathrm{m}$ thick, formed by an ixotrichodermium, with terminal cells 43-92 × 5-11 $\mu \mathrm{m}$, broadly clavate, sublanceolate, some isodiametric, thick-walls $(0.8 \mu \mathrm{m})$, hyaline in $\mathrm{KOH}$, yellow in Melzer. Stipitipellis $150-160 \mu \mathrm{m}$ thick, formed by a stratum of caulocystidia 29-95 × 14-19 $\mu \mathrm{m}$, fusoid, cylindrical, septate, hyaline in $\mathrm{KOH}$, yellow in Melzer solution, walls $0.8 \mu \mathrm{m}$, with very fine content visible in Melzer. Clamp connections absent

Habitat - Solitary to scattered, growing in humus of oak forest, associated to Quercus liebmanii, ectomycorrhizal sporophores found from July to October.

Edibility - Edible.

Known distribution - Eastern Canada, United States, Mexico, Costa Rica and Dominican Republic in the Caribbean (Singer et al. 1992, Bessette et al. 2017, Ortiz-Santana et al. 2007).

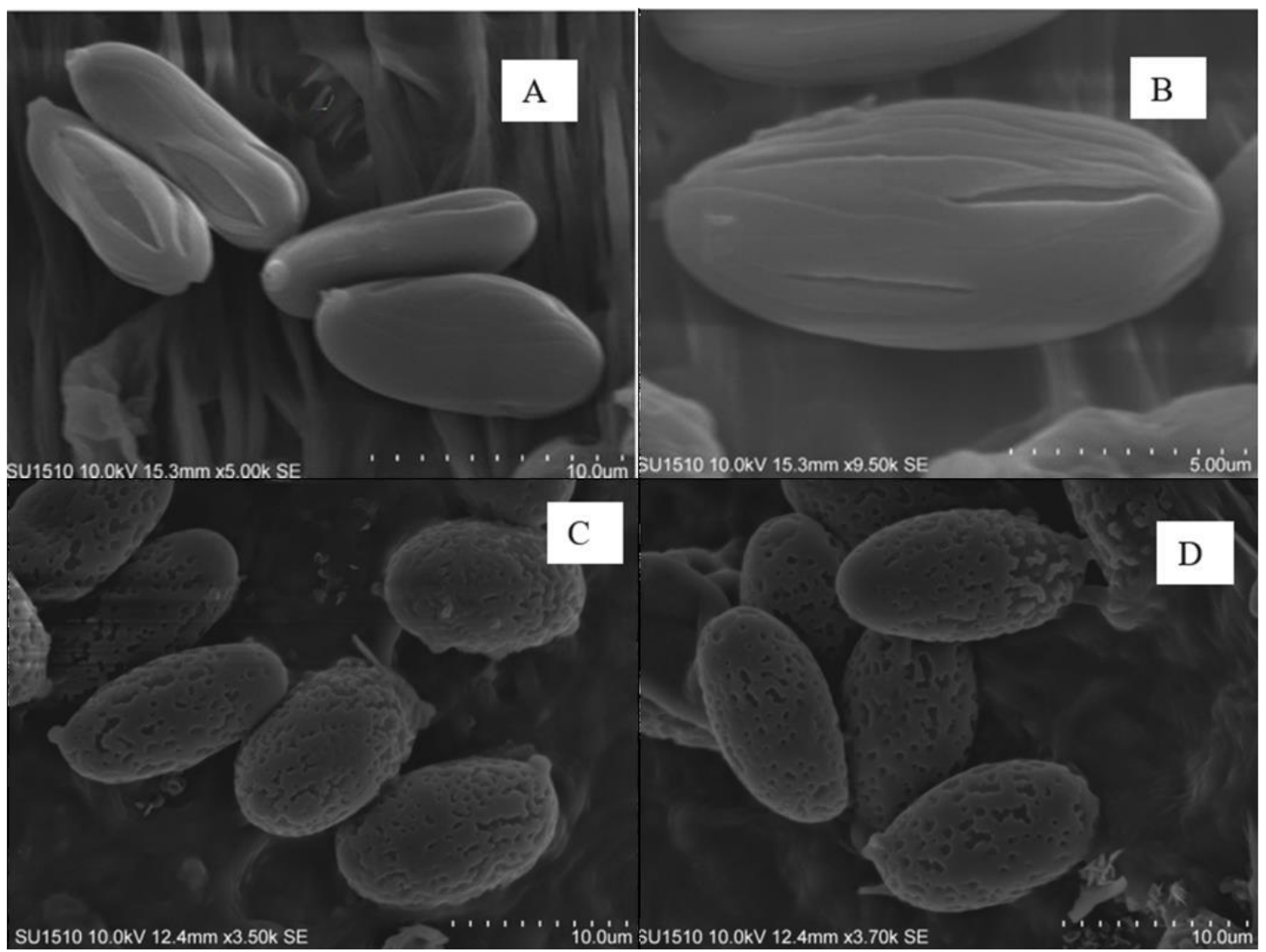

Fig. 4 - Ornamented basidiospores. A-B Aureoboletus russellii, (ENCB- ITCV, 640). C, D Austroboletus gracilis (ENCB-ITCV, 356).

Examined materials - MÈXICO, OAXACA, District Oaxaca de Juárez, municipality San Antonio de la Cal, at an altitude 2039 m, 3 June 2014, Ayala-Vásquez, 427 (ENCB), 356 (ENCBITCV) MÈXICO, OAXACA. District Oaxaca de Juárez, municipality San Antonio de la Cal, altitude 2045 m, 4 September 2014, Ayala-Vásquez, 424, 483(ENCB), District Oaxaca de Juárez, municipality San Antonio de la Cal, 4 October 2014, Ayala-Vásquez 524, 525 (ENCB), 527, 528 
(ENCB-ITCV), District Oaxaca de Juárez, municipality San Antonio de la Cal, altitude 2110 m, 16 July 2016, Ayala-Vásquez, 649 (ITCV), OAXACA. District Oaxaca de Juárez, municipality San Antonio de la Cal, altitude 2090 m, 16 June 2016, Ayala-Vásquez-Victores-Aguirre 1160 (ITCV). Notes - Austroboletus gracilis is characterized by pileus of brown-yellowish, grayish-brown and black-brown, finely scaly, the stipe thin and cylindrical to slightly bulbous and the spores pitted, elliptical to ovoid, agrees with those described Ortiz-Santana et al. (2007), García-Jiménez (1999).

Boletellus ananiceps (Berk.) Singer [as ‘ananaeceps'], Sydowia 9(1-6): 423 (1955).

Figs 5A-I, 10B

$\equiv$ Boletus ananiceps Berk. [as 'ananæceps'] 1872

Pileus 120-170 mm diameter, convex when young, planate-convex when maturity, light brown (5D4-D5-D6), pinkish-white (8A2), membranous margin with projections, surface with obtuse scales, verrucose to squamulose, finally areolated in maturity, dry. Hymenophore free to depressed, pores 1-2 mm diameter, round to hexagonal, greyish yellow (4C6), orange yellow (4B8), dark brownish (6F8) at maturity, tubes $20-25 \mathrm{~mm}$ long, concolored with the pores, turns grayish blue (21C4-21C5) when in contact with air. Stipe190 $\times 27 \mathrm{~mm}$ in the apical part, $15 \mathrm{~mm}$ in the middle part and with a basal bulb measuring $30 \mathrm{~mm}$ in the basal part, clavate, smooth, dry, glabrous, dirty white when young, brownish orange (5C3) at maturity. Context: 10-18 mm, white, when cut with the air becomes pale pink (11A3) then greyish blue (21C4), stipe turns ruby (12E8), stipe context fibrillose, when cut turns grayish blue (21C4) in the apex, pink (11A3) in the middle zone, ruby (12E8) in the basal part. White mycelium.

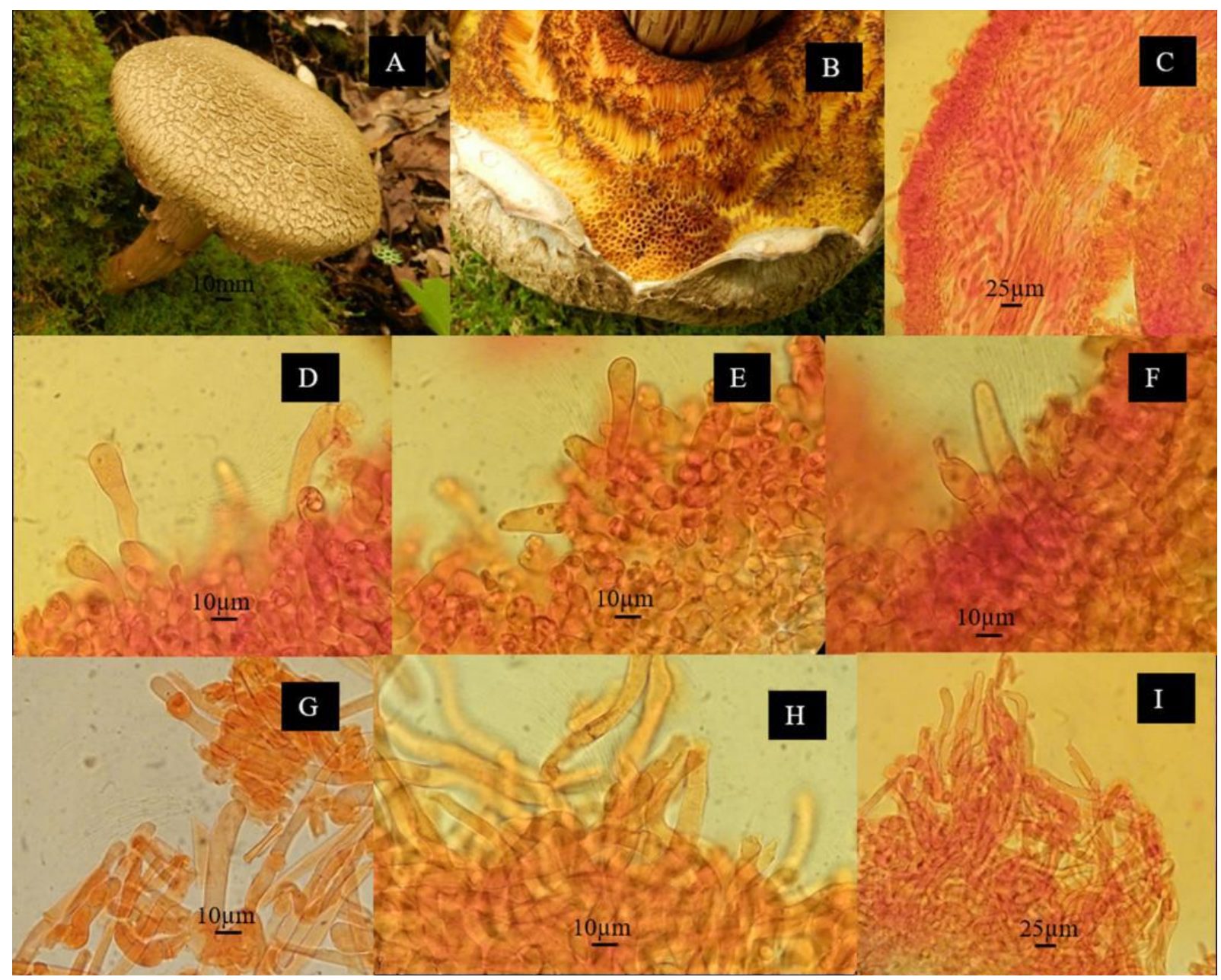

Fig. 5 - Boletellus ananiceps (ENCB-ITCV, 406). A-B Fresh basidiomata in the field. $\mathrm{C}$ Transverse section through tube showing trama. D Basidia. E Pleurocystidia. F Cheilocystidia. G Caulocystidia. H-I Pileipellis. 
Chemical reactions. The $\mathrm{KOH}$ on the surface of the pileus, context and stipe is negative.

Basidiospores 16-19 (-22) × 7-8 (-9) $\mu \mathrm{m}, \mathrm{Q}=2.4, \mathrm{~N}=30)$, ellipsoid with fusiform, yellowishbrown to golden, with suprahilar depression, with ornamentation of deep longitudinal striations, without transverse striations, sometimes anastomosed, truncated with projections $0.7-1 \mu \mathrm{m}$. Basidia 43-50 × 14-15 $\mu \mathrm{m}$, clavate, four-spored. Pleurocystidia 45-57 $\times 11-15 \mu \mathrm{m}$, fusiform some ventricose, hyaline to pale brown in $\mathrm{KOH}$. Cheilocystidia 46-57 $\times 9-12 \mu \mathrm{m}$, fusiform-ventricose, brown-orange, thick-wall $(1 \mu \mathrm{m})$. Hymenophoral trama boletoid; hyphae subcylindrical to cylindrical, 5-14 $\mu \mathrm{m}$ wide, thick-walls, hyaline in $\mathrm{KOH}$, with septa. Pileipellis $250-300 \mu \mathrm{m}$ thick, trichodermium, with terminal cells 32-60 × 7-12 $\mu \mathrm{m}$, cylindrical, subclavate, elongated, pale yellow, thick-walls $(1 \mu \mathrm{m})$, with septa. Stipitipellis $150 \mu \mathrm{m}$ thick, formed by caulobasidia $25-45 \times$ 6-15 $\mu \mathrm{m}$, clavate to subfusiform, hyaline with pale yellow in $\mathrm{KOH}$, thin-walls. Clamp connections absent.

Habitat - Solitary, growing in humus in cloud forest, forming ectomycorrhizal associations with Quercus laurina, sporophores found from August to October.

Edibility - unknown

Distribution - Costa Rica, Queensland, Australia (Singer 1955, Pegler \& Young 1981, Singer et al. 1992, Halling et al. 2015). This species is registered for the first time in Mexico.

Examined materials - MEXICO, OAXACA, District Santiago Zacatepec Mixe, Municipality Mixistlán de la Reforma, Santa María Mixistlán, 4 October 2014, O. Ayala-Vásquez 392 (ENCB, ITCV), District Santiago Zacatepec Mixe, Municipality Mixistlán de la Reforma, Santa María Mixistlán, 5 August 2016, O. Ayala-Vásquez 972 (ITCV).

Notes - Boletellus ananiceps is characterized macroscopically by the pale brown pileus, surface with very pronounced triangular scales, yellow to yellow olive hymenophore which the cut turns blue, the stipe subclavate with bulbous base, and fibrillose, smooth, glabrous surface. The basidiospores present deep longitudinal striations without transverse striations, characteristic that distinguishes it from $B$. ananas. Described specimens agree with the description by Singer et al. (1992).

Boletellus coccineus (Sacc.) Singer, Beih. Nova Hedwigia 105: 6 (1992) Figs 6A-I, 10A $\equiv$ Boletellus minor (Singer) L.D. Gómez, Revta Biol. trop. 44(Suppl. 4): 69 (1997) [1996]

BBoletus coccineus Fr., Epicr. syst. mycol. (Upsaliae): 423 (1838) [1836-1838]

EStrobilomyces coccineus Sacc., Syll. fung. (Abellini) 6: 50 (1888)

Pileus 70-100 mm diameter, convex when young, planate-convex when maturity, light pink (13A3), light brown (4C4), on whitish edges (4A2), dry surface, rimose, scaly, with whitish projections corresponding to the remains of a veil that binds to the stipe in their juvenile phases. Hymenophore depressed around the stipe, circular to angular pores $0.5-1 \mathrm{~mm}$ diameter, mustard greyish yellow (4B6), turning orange-brown (6C7) with age, grayish-blue bruises (24C5) when touched; Tubes 10-12 mm long, concolored with the pores. Stipe 63-95 $\times 6-15.2 \mathrm{~mm}, 6 \mathrm{~mm}$ in the apical part, $15.2 \mathrm{~mm}$ at the base, clavate, bulbous base, fibrillose surface, squamulose when young, whitish when young, greyish yellow (4B4), light brown (5D5) at maturity, with a red(10A8) or pink(12A5) on the apex. Context of $12 \mathrm{~mm}$ thick in the center, $3 \mathrm{~mm}$ on the edges, white, bluegreyish (24C5) when bruised, with fungoid odor, slightly acidic sweet taste.

Chemical reactions. Surface of pileus and stipe reddish brown in $\mathrm{KOH}$.

Basidiospores 13.6-15.7 (-17.6) × 4.8-6 (-7.2) $\mu \mathrm{m},(\mathrm{Q}=2.6, \mathrm{~N}=30)$ cylindrical, with visible suprahilar depression, with longitudinal striations and transverse striations, golden to brown in $\mathrm{KOH}$, golden in Meltzer. Basidia 32-48 $\times 8.8-11.2 \mu \mathrm{m}$, broadly clavate with content in Meltzer, two-four spored, hyaline in $\mathrm{KOH}$. Pleurocystidia 32-40 $\times 7.2-11.2 \mu \mathrm{m}$, ventricose-mucronate, brown color in $\mathrm{KOH}$. Cheilocystidia 36-48, $8 \times 8.8-11.2 \mu \mathrm{m}$, ventricose-mammillate, clavatemucronate with contents in Meltzer, hyaline in $\mathrm{KOH}$, thick-walls $(1 \mu \mathrm{m})$. Hymenophoral trama boletoid; hyphae cylindrical, 3-8 $\mu \mathrm{m}$ wide, hyaline in $\mathrm{KOH}$, with very fine content in Meltzer reagent. Pileipellis 200-280 $\mu \mathrm{m}$ thick, thick, formed by a trichodermium with terminal cells 20-52 $\times 6.4-10.4 \mu \mathrm{m}$, cylindrical to clavate, broadly rounded, subcapitate with an apical septum, hyaline 
in $\mathrm{KOH}$, thick-walls. Stipitipellis $90-130 \mu \mathrm{m}$ thick, caulocystidia $22.4-56 \times 5.6-9.6 \mu \mathrm{m}$, cylindrical to clavate, rounded apex, pale brown to hyaline in $\mathrm{KOH}$, brown in Meltzer thin-wall.

Habitat - Solitary, growing in humus of oak forests, associated forming ectomycorrhizal with Quercus scytophylla, Q. martinezii, Pinus teocote from August to October.

Edibility - edible.

Examined materials - MEXICO, OAXACA, District Oaxaca de Juárez, Municipality San Antonio de la Cal, East in forest of Quercus martinezii, 4 October 2014, Ayala-Vásquez 544 (ENCB), District Santiago Zacatepec Mixe, municipality Mixistlán de la Reforma, East Oak forest of Q. scytophylla, 6 October 2014, Ayala-Vásquez 594 (ENCB), District Santiago Zacatepec Mixe, municipality Mixistlán de la Reforma, Santa María Mixistlàn locality, Pine-Oak forest, 1500m, 2 August 2017, Ayala-Vásquez 943 (ITCV), District Santiago Zacatepec Mixe, municipality Mixistlán de la Reforma, Santa María Mixistlàn locality, Oak forest, 22 July 2017, Ayala-Vásquez 884 (ITCV), District Santiago Zacatepec Mixe, municipality Mixistlán de la Reforma, Santa María Mixistlàn locality, cloud forest, 8 June 2017, Ayala-Vásquez 964 (ITCV), District Santiago Zacatepec Mixe, municipality Mixistlán de la Reforma, Santa María Mixistlàn locality, Oak forest, 25 July 2017, Ayala-Vásquez 902 (ITCV), District Santiago Zacatepec Mixe, municipality Mixistlán de la Reforma, Santa María Mixistlàn locality, cloud forest, 5 August 2017, AyalaVásquez 976 (ITCV), District Santiago Zacatepec Mixe, municipality Mixistlán de la Reforma, Santa María Mixistlàn locality, Oak-Pine forest, 14 September 2017, Ayala-Vásquez 1036 (ITCV)

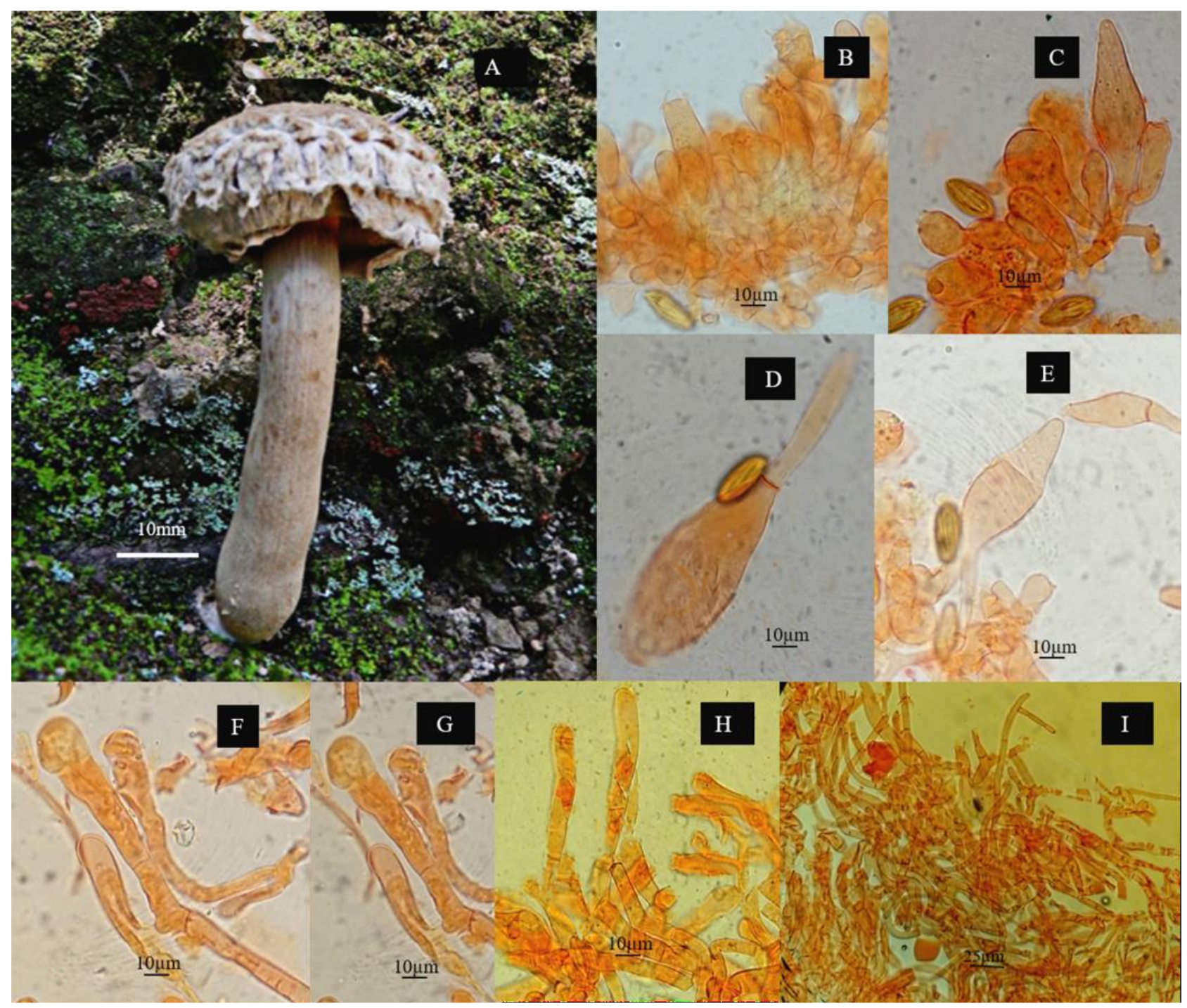

Fig. 6 - Boletellus coccineus (ITCV-724). A Fresh basidiomata in the field. B basidia. C Pleurocystidia. D-E Queilocystidia. F-G Caulocystidia. H-I Pileipellis. 
Known distribution - It is distributed in North America and Central America (Singer 1945, Singer et al. 1992).

Notes - Boletellus coccineus is characterized by presenting a pinkish or red scaly surface, sometimes paler at maturity. The spores present longitudinal and transverse striations not as deep as those of B. ananiceps. The studied material coincides B. ananas var. minor described by Singer et al. 1992, Singer 1983.

Boletellus chrysenteroides (Snell) Snell Mycologia 33(4): 422 (1941)

Figs 7A-I, 10D-E

$\equiv$ Boletus chrysenteroides Snell, Mycologia 28(5): 468 (1936)

Pileus 56-80 $\mathrm{mm}$ in diameter, convex when young, planate-convex when maturity, dark brown $(5 \mathrm{~F} 4,5 \mathrm{~F} 3)$, the sterile margin yellowish brown (5E5), dry surface, tomentose, flocculose, in the adult stage somewhat areolate. Hymenophore adnate, rounded to angular round pores $0.5 \mathrm{~mm}$, vivid yellow (3A8) to olive-yellow (30A8-30B8), turns grayish-blue (21E7-21E6) when touched; tubes 6-7 mm long, grayish-yellow (2B5, 2B6), olive-yellow (3D7) in the maturity. Stipe $70 \times$ $40 \mathrm{~mm}$, cylindrical to ventricose, fibrillose surface, flocculose, scabrous, apex yellow (4A8) to red (7A5) color, the rest concolored with the pileus. Context $7 \mathrm{~mm}$ thick, white to pale yellow, when bruised the margin becomes pale red (9A4) mainly at the base of the stipe, the rest is blue (21E7). Basal mycelium: whitish.

Chemical reaction: when applying $\mathrm{KOH}$, the pileus surface turns black, on hymenophore turns brown, on context brown-orange and dark brown on the stipe surface.

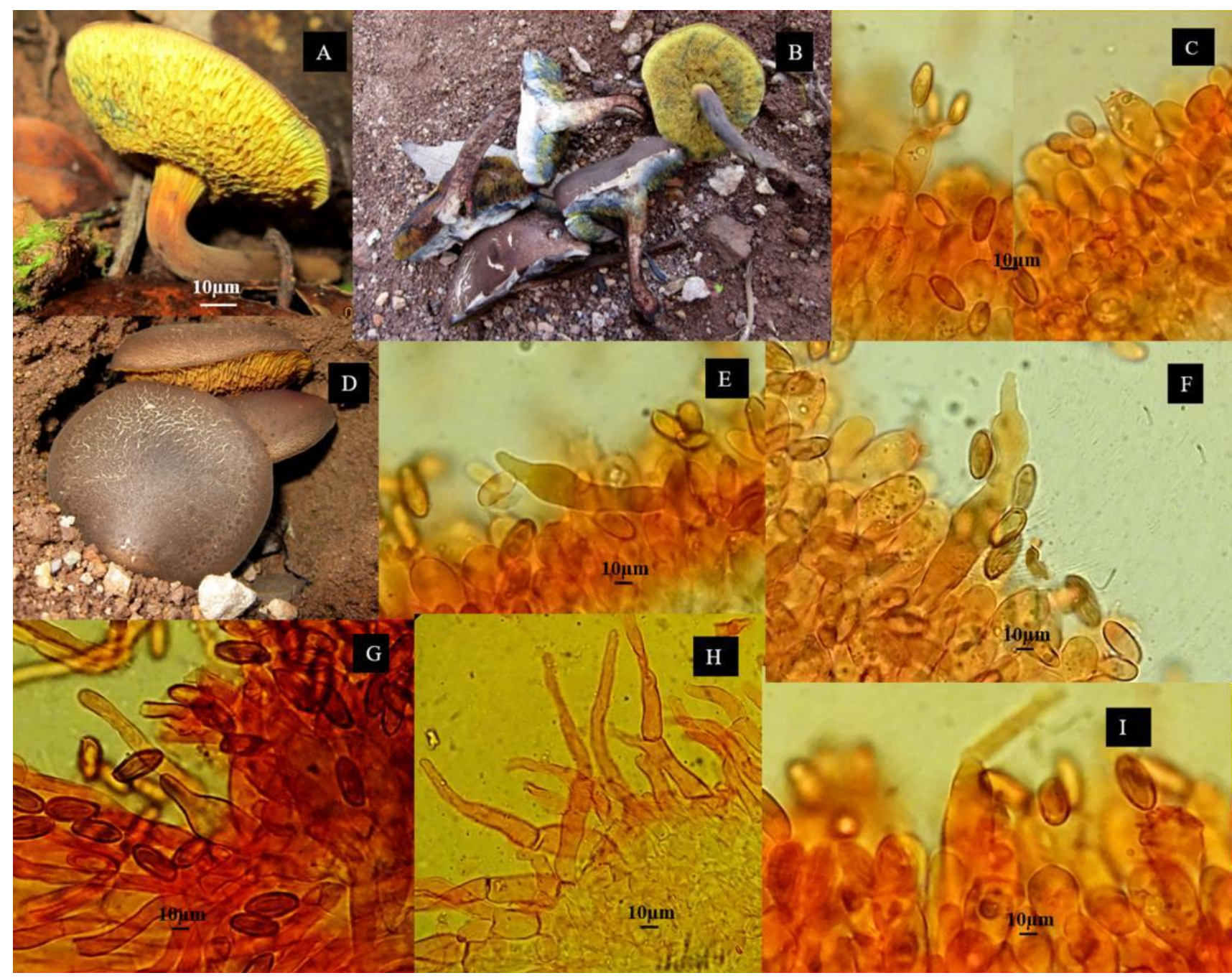

Fig. 7 - Boletellus chrysenteroides (ITCV-763). A-B, D Fresh basidiomata in the field. C Basidia. E Pleurocystidia. F, I Cheilocystidia. G Caulocystidia. H Pileipellis. 
Basidiospores 9-14 $(-17) \times 6-8 \mu \mathrm{m},(\mathrm{Q}=2.3, \mathrm{~N}=30)$ ellipsoid oblong, fusoid, with longitudinal and transverse striations visible in SEM, with visible suprahilar depression, brown in $\mathrm{KOH}$, yellow-brownish in Meltzer reagent. Basidia 36-48 $\times 10-16 \mu \mathrm{m}$, clavate, with content, hyaline in $\mathrm{KOH}$, four-spored. Pleurocystidia 40-55 (-70) $\times$ 9.0-12 (-14) $\mu \mathrm{m}$, mucronate, ventricose-rostrate, clavate, yellow, thin-walls, with granulose content in Meltzer. Cheilocystidia 40-60 × 10.4-14.4 $\mu \mathrm{m}$, ventricose-rostrate, hyaline to pale brown in $\mathrm{KOH}$, thin-walls, with brown content in Meltzer. Hymenophoral trama boletoid; hyphae gelatinized, cylindrical, 2.4-8 $\mu \mathrm{m}$ wide, hyaline in $\mathrm{KOH}$, with very fine content in Meltzer, thin-walled. Pileipellis 210-250 $\mu \mathrm{m}$ thick, composed of trichodermium, with terminal cells $22-50 \times 8-13 \mu \mathrm{m}$, subfusoid, cylindrical with acute apex, hyaline to yellowish brown in $\mathrm{KOH}$, with brown content in Meltzer, thin-walled. Stipitipellis 90-140 $\mu \mathrm{m}$ thick, caulocystidia 17-50 $(-55) \times 7-14 \mu \mathrm{m}$, clavate-cylindrical, ventricose-rostrate, mucronate, golden in $\mathrm{KOH}$, measured brown content in Meltzer, with caulobasidia 36-46 × 10-15.2 $\mu \mathrm{m}$, hyaline in $\mathrm{KOH}$, four-spored.

Habitat - Solitary to scattered, growing in humus of oak forest, associated forming ectomycorrhizas with Quercus rugose and Q. scytophylla, in oak-pine forests, from August to November

Examined material - MÈXICO, OAXACA, District Santiago Zacatepec Mixe, Municipality Mixistlán de la Reforma, Santa María Mixistlán, 5 September 2014, Ayala-Vásquez 472 (ENCBITCV), District Santiago Zacatepec Mixe, Municipality Mixistlán de la Reforma, Santa María Mixistlán, 01 November 2016, Ayala-Vásquez, 763 (ITCV).

Known distribution - Canada and United States (Singer 1945, Snell \& Dicks 1970). In Mexico (Singer et al. 1992, García-Jiménez 1999); in Central America it has been reported in Honduras by Ortiz-Santana et al. (2007). In the present work it was located in the region of the Sierra Norte. This is the first record of Oaxaca state.

Notes - Boletellus chrysenteroides is characterized by presenting the basidiospores with longitudinal striations and transverse striations, measuring 10-14 (17.4) $\times 6-8 \mu \mathrm{m}$. The described material agrees with the type material described by Snell (1936). Boletelllus chrysenteroides can be confused with $B$. flocculosipes by the similarity in the color of the basidioma, but can be distinguished for having the shortest spores and not have transversal striations (Singer et al. 1992).

Boletellus flocculosipes (Murrill) Perr.-Bertr., Annls Sci. Nat., Bot. Biol. Vég., sér. 12 5: 764 (1965) [1964]

EBoletus flocculosipes Murrill, Mycologia 41(4): 491 (1949)

Figs 8 A-H, 10C

Pileus 100-110 mm diameter, convex when young, planate-convex when maturity, brown color (5F8), surface fibrillose, flocculose, dry, margin with whitish to greyish veil remains of veil. Hymenophore subadnated, depressed around the stipe, pores 2-2.5 $\mathrm{mm}$ diameter, angular, yellow (2A8-2B8) to olive yellow (30A7), brown (5F8) in maturity, turns blue (23D8) when touched, tubes $10 \mathrm{~mm}$ longitude, concolored with the pores. Context of the pileus white to light yellow, turning grayish blue in the pileus when cut, and reddish brown (8C6) at the stipe base. Stipe 53-55x $2-7 \mathrm{~mm}$, subclavate, rough striated surface, tomentose, yellow (2A8-2B8) at the apex, rest of the stipe red brown (8E6) to reddish orange (8B7), when mature the basal zone is violet-gray (10F3).

Chemical reaction when $\mathrm{KOH}$ is applied the surface of the pileus turns dark brown, and the context, stipe and hymenophore ochraceous brown color.

Basidiospores 10-16 × 5-8 $\mu \mathrm{m},(\mathrm{Q}=1.9, \mathrm{~N}=30)$, elliptic-oblong, somewhat truncated, reddish-brown in $\mathrm{KOH}$, reddish in Meltzer, with or without suprahilar depression; ornamentation longitudinally striated or winged 3-5 wings-stretch marks. Basidia 26-36 $\times 9-11 \mu \mathrm{m}$, clavate, twofour spored, hyaline to pale brown in $\mathrm{KOH}$ with content in Meltzer. Pleurocystidia 38-45 $\times 9-15$ $\mu \mathrm{m}$, ventricose-ampullaceous, fusoid, hyaline to brown in $\mathrm{KOH}$. Cheilocystidia $47-50(-65) \times 10$ $15(-22) \mu \mathrm{m}$, lageniform, ventricose-rostrate, brown in $\mathrm{KOH}$, thick-wall, with content in Meltzer solution, hyaline apex. Hymenophoral trama boletoid; hyphae gelatinized, cylindrical, 2.4-8.4 $\mu \mathrm{m}$ wide, hyaline or brown in $\mathrm{KOH}$, brown-yellow in Meltzer, thin-walled. Pileipellis 80-130 $\mu \mathrm{m}$ thick, formed by a dermis with terminal cells $27-54 \times 8-18 \mu \mathrm{m}$, cylindrical, septate, brown-cinnamon in 
$\mathrm{KOH}$, Stipitipellis 50-55 $\mu \mathrm{m}$ thick, caulocystidia $26-40 \times 9-13 \mu \mathrm{m}$, ventricose-rostrate, napiform or clavate, hyaline to yellowish brown in $\mathrm{KOH}$, with content in Meltzer. Caulobasidia 26-36 × 9$11 \mu \mathrm{m}$, broadly clavate, hyaline to pale yellow in $\mathrm{KOH}, 2-4$ spored.

Habitat - Solitary, growing in humus of Oak-Pine forests, is very common in cloud and oak forests, forming ectomycorrhizal with Quercus carya and Quercus liebmanii, from July-August, at 2120-2700 m.

Edibility - Unknown

Examined material - MEXICO, OAXACA, District Oaxaca de Juárez, Municipality de Santa María el Tule, Ayala-Vásquez,16 July 2016, 656 (ITCV).

Known distribution - United State and Mexico (Singer et al. 1992, García-Jiménez 1999).

Notes - Boletellus flocculosipes is akin to Boletellus chrysenteroides, except for its spores which are not interconnected by transverse striations. There is a close relationship with Boletellus pictiformis except for the strongly tomentose or scaly pileus. The basidiospores of the studied material are longer, but narrower as they measure 10-16 $\times 5.5-6.8 \mu \mathrm{m}$, compared to the type species described by Murrill (1949) which measure 12-14 ×6 -7 $\mu \mathrm{m}$. The described species agrees with those by Singer et al. (1992).

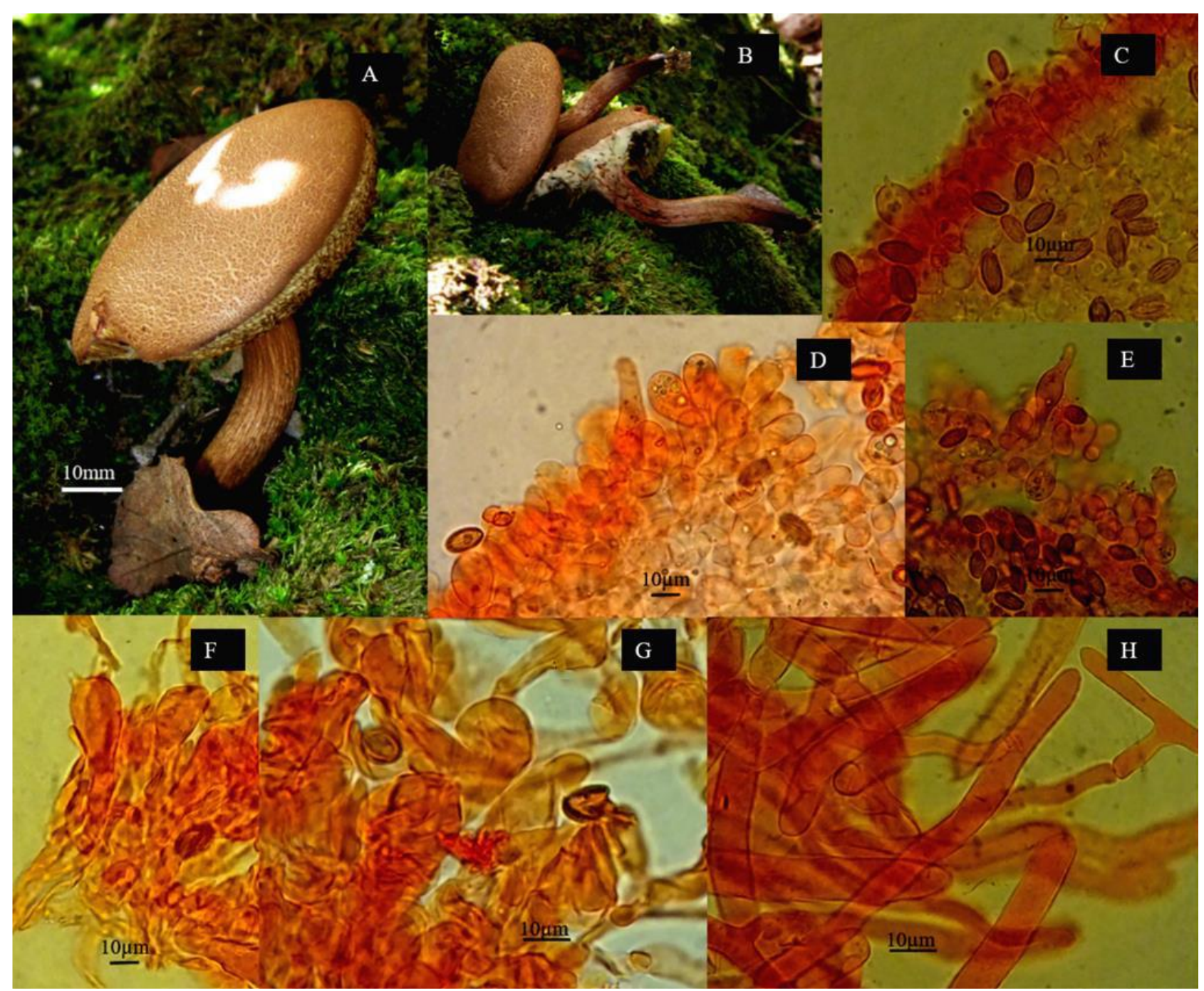

Fig. 8 - Boletellus flocculosipes (ITCV-656). A-B Fresh basidiomata in the field. C Basidia. D Pleurocystidia. E Cheilocystidia. F-G caulocystidia. H Pileipellis.

Boletellus pseudochrysenteroides A.H. Sm. \& Thiers [as 'pseudo-chrysenieroides'], Boletes of Michigan (Ann Arbor): 384 (1971).

Figs 9A-H, 10F 
Pileus $40 \mathrm{~mm}$ in diameter, convex when young, planate-convex when maturity, carmine red (10A8) to reddish-pink (10A3), surface strongly pruinose, finely velutinose to tomentose to rimoseareolate in maturity, with incurvate margin. Hymenophore, depressed subadnate, pores $0.5-1.2 \mathrm{~mm}$ diameter, angular, yellow (4A8) to brown-orange (5C5) in maturity, stained with blue when touched, tubes $4 \mathrm{~mm}$ longitude, yellow, stained with blue when touched. Context of $10 \mathrm{~mm}$ thick, fleshy, whitish to pale yellow, with a reddish stain under the cuticle, stained with blue when exposed. Stipe $45 \times 6 \mathrm{~mm}$, cylindrical, smooth surface to finely furfuraceus, whitish towards the apex, with orange-brown (5C5) to reddish-purple (9C7) dyes in the rest of the context.
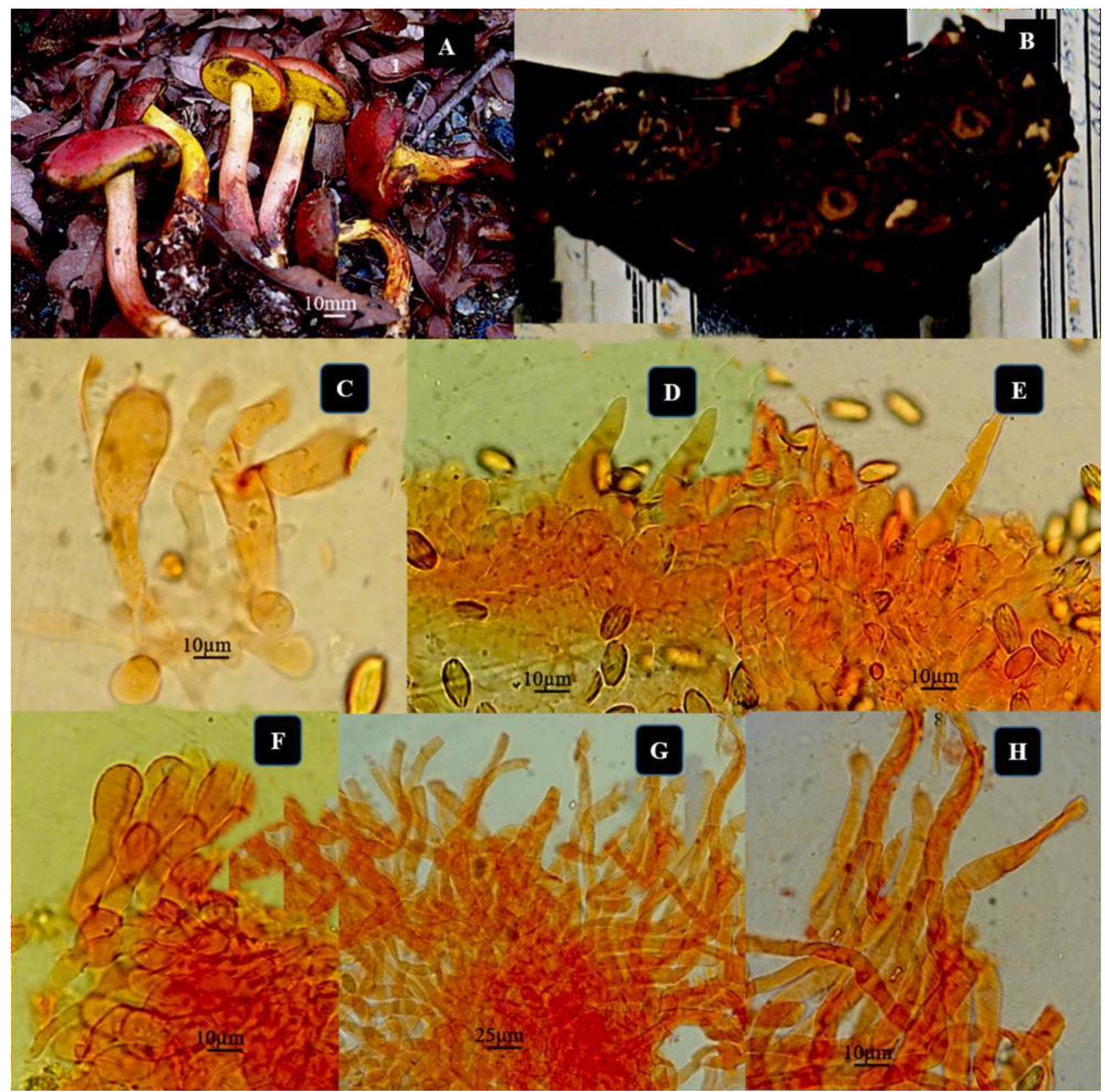

Fig. 9 - Boletellus pseudochrysenteroides. A Fresh basidiomata in the field. B Basidiomata in herbarium (MEXU-10579). C Basidia. D Pleurocystidia. E Cheilocystidia. F caulocystidia. $\mathrm{G}-\mathrm{H}$ Pileipellis.

Basidiospores 12.8-15.1 (-18.4) × 4.8-6.6 $\mu \mathrm{m},(\mathrm{Q}=2.8, \mathrm{~N}=30)$, ellipsoids to fusoids, some truncated, with the middle part wider, with a visible suprahilar depression, ornamented with 10 to 12 very superficial longitudinal striations of yellowish-brown color in $\mathrm{KOH}$, golden in Meltzer. Basidia 32-48 $\times$ 8.8-12 $\mu \mathrm{m}$, clavate, hyaline when content in $\mathrm{KOH}$, two-four spored. 
Pleurocystidia 32-38.4 × 8-12 $\mu \mathrm{m}$, mucronate, fusoid-ampullaceous, hyaline some pale brown. Cheilocystidia 56-72 $(-100) \times 8-12 \mu \mathrm{m}$, fusoid-ampullaceous, hyaline to pale brown, with medium to long neck. Hymenophoral trama boletoid; hyphae gelatinized, cylindrical, 2-14.4 $\mu \mathrm{m}$ wide, hyaline in $\mathrm{KOH}$, pale brown in Meltzer, thin-walls. Pileipellis 70-95 $\mu \mathrm{m}$ thick, formed by an epicutis with terminal cells37-45 $\times$ 5.5-6.4 $\mu \mathrm{m}$, fusoid, mucronate, hyaline in $\mathrm{KOH}$, with incrustations in Meltzer, thin-wall. Stipitipellis 57-76 $\mu \mathrm{m}$ thick, caulocystidia 20-60 × 6.4-12 $\mu \mathrm{m}$, fusoid-rostrate, clavate, mucronate, hyaline in $\mathrm{KOH}$, with thin-walls.

Habitat - Solitary, growing in humus of oak forest, associated forming ectomycorrhizas with Quercus spp., at an altitude 1930 m, during the month of September.

Examined material - México, Oaxaca. District of Ixtlán de Juárez, municipality of Santa María Jaltianguis, E. Pérez, R. Hernández and E. Aguirre, July 1975 (MEXU-10579).

Known distribution - United States and Mexico (Smith \& Thiers 1971, García-Jiménez 1999). This is the first record in Oaxaca state.

Notes - Boletellus pseudochrysenteroides is characterized by the red carmine or reddish pink color of the pileus, the pores are bright yellow, stained with blue when touched, the stipe is concolored with the pileus or somewhat orange, strongly pruinose, with yellow context and is stained blue quickly. It agrees with the description by Singer et al. (1992), García-Jiménez (1999).

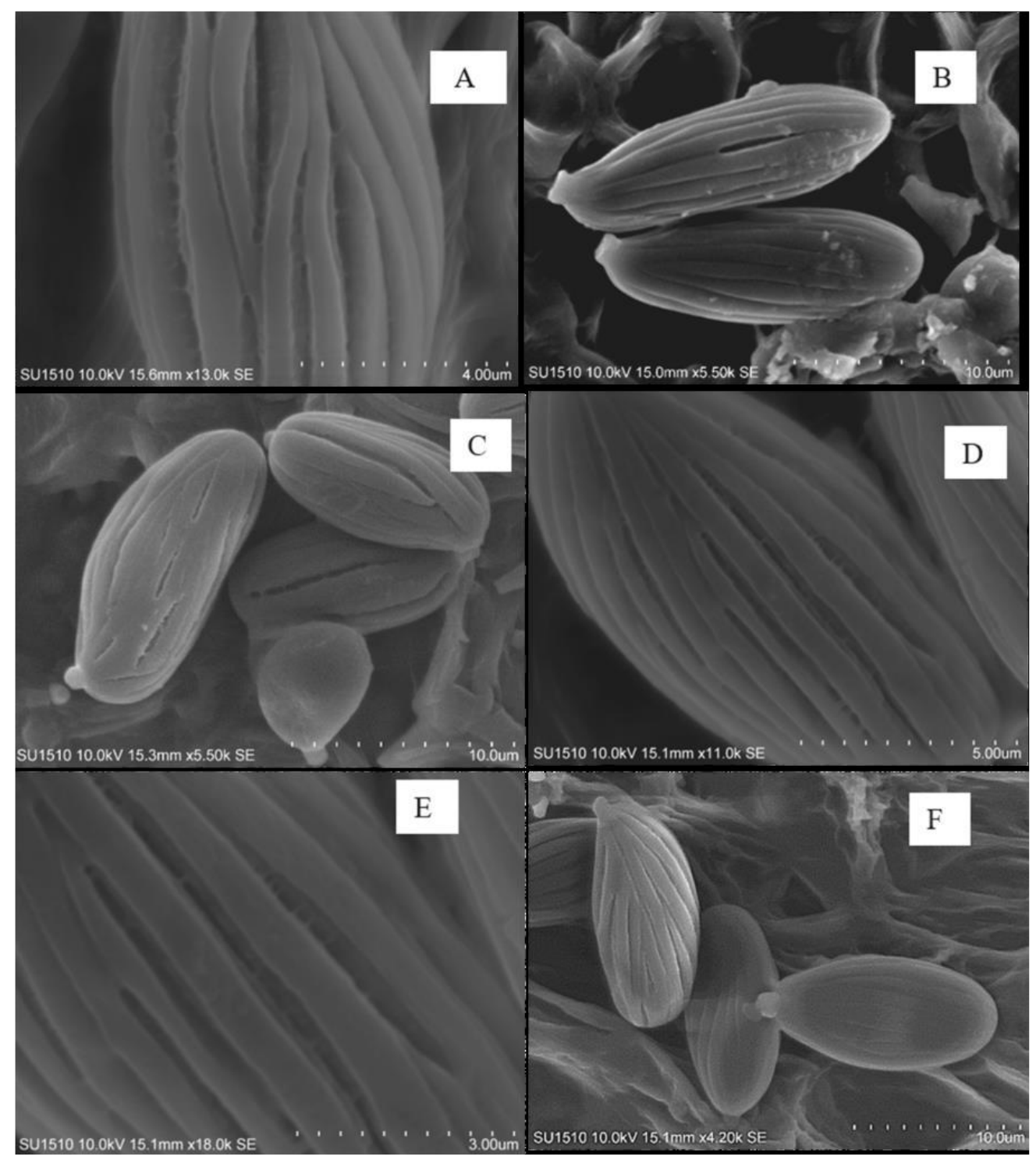

Fig. 10 - Ornamented basidiospores. A Boletellus ananas (ENCB - 544). B Boletellus ananiceps (ENCB-ITCV, 406). C Boletellus flocculosipes (ITCV- 656). D, E Boletellus chrysenteroides (ENCB-ITCV, 472). F Boletellus pseudochrysenteroides (MEXU-10579). 
Heimioporus betula (Schwein.) E. Horak Sydowia 56(2): 239 (2004)

Figs 11A-8I, 14A

三Austroboletus betula (Schwein.) E. Horak, Sydowia 33: 72 (1980)

$\equiv$ Boletellus betula (Schwein.) E.-J. Gilbert, Les Livres du Mycologue Tome I-IV,Tom. III: Les Bolets: 108 (1931)

$\equiv$ Boletus betula Schwein., Schr. naturf. Ges. Leipzig 1: 90 (1822)

$\equiv$ Ceriomyces betula (Schwein.) Murrill, Mycologia 1(4): 144 (1909)

$\equiv$ Frostiella betula (Schwein.) Murrill, Contr. Herb. Univ. Fla. Agr. Exp. Stat. Gainesville: Jan. 5 1942: 6 (1942)

Pileus 70-100 mm, convex when young, planate-convex when maturity, color brownishorange (7C6), reddish-brown (8E7) with orange (5A7) tones, surface smooth, viscid, shiny, glabrous, narrow and sterile margin. Hymenophore subdecurrent, depressed at the talk, pores 0.5-1 $\mathrm{mm}$, angular, yellow (30A8), in the ripe stage olive-yellow $(30 \mathrm{~B} 8,30 \mathrm{C} 8)$, tubes $15 \mathrm{~mm}$ long, concolored to the pores. Stipe $30-110 \times 10 \mathrm{~mm}$, cylindrical-subclavate, solid, surface with a prominent reticle up to the apex, yellow (4A8) at first, becoming reddish (10C8). Context of pileus $15 \mathrm{~mm}$ thick, white, yellow (1A2) with pink (10A2) tones when bruised. Basal mycelium white to yellowish white (1A2). Spore print olive brown.

Chemical reaction: context in $\mathrm{KOH}$ yellowish brown (5E6), hymenophore dark brown (5F8), negative on the stipe.

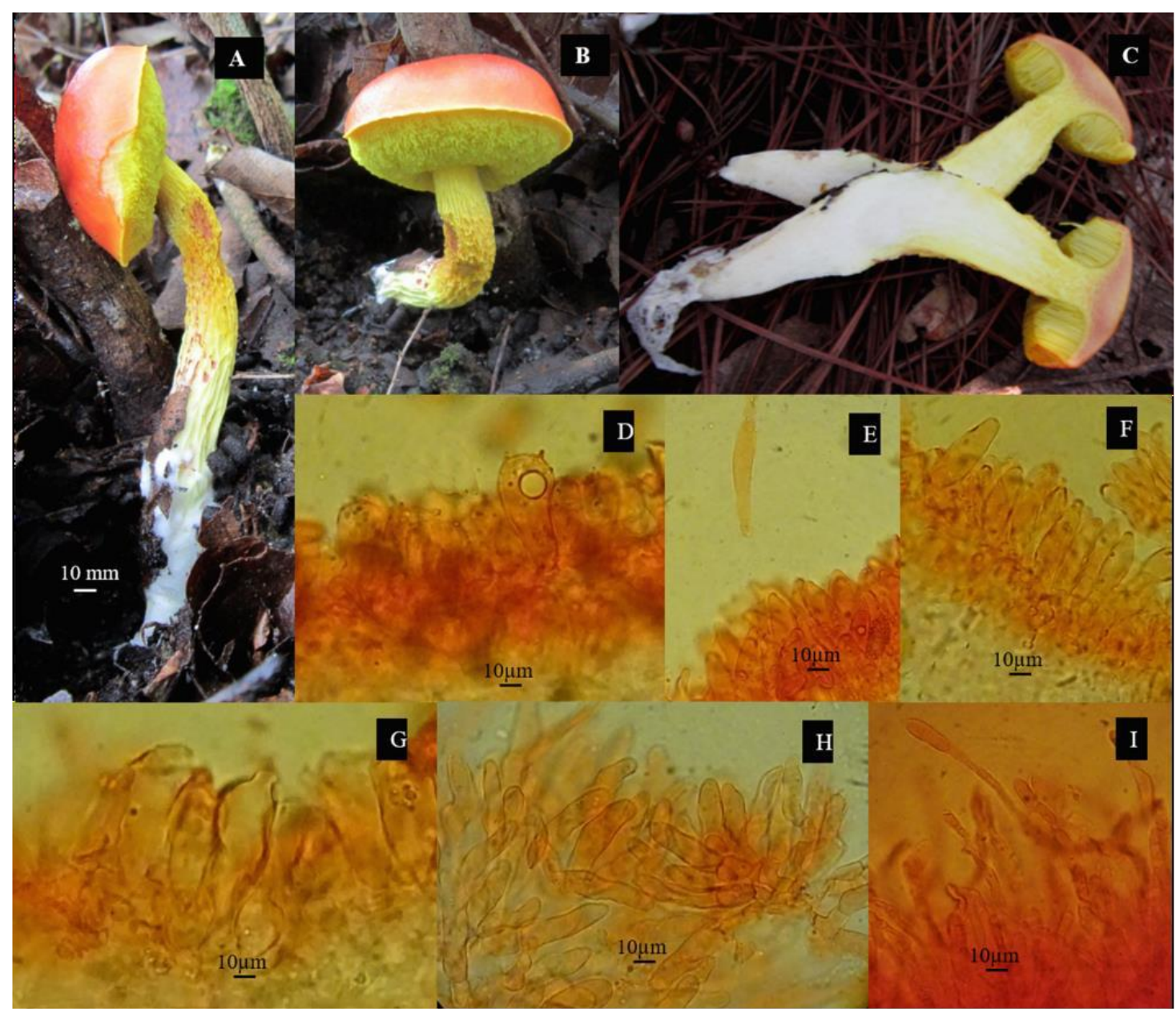

Fig. 11 - Heimioporus betula (ENCB-ITCV, 354). 1-3 Fresh basidiomata in the field. 4 Basidia. 5-6 Pleurocystidia. 7 Cheilocystidia. 8 Caulocystidia. 9 Pileipellis.

Basidiospores 16-18.5 $(-23) \times 7.5-9(-10.5) \mu \mathrm{m},(\mathrm{Q}=2.1, \mathrm{~N}=30)$, ellipsoid, subfusiform, with suprahilar depression, apiculum conspicuous, superficially and discontinuously reticulate, golden yellow to pale brown in Meltzer and $\mathrm{KOH}$. Basidia 26.4-40 × 9.6-13.6 $\mu \mathrm{m}$, clavate, four- 
spored, hyaline in $\mathrm{KOH}$. Pleurocystidia 30.2-40 $\times 11.2-15.2 \mu \mathrm{m}$, clavate, fusoid-rostrate, thickwalls with content in Meltzer, hyaline to brown in $\mathrm{KOH}$. Cheilocystidia 32- $44 \times 9.6-12.8 \mu \mathrm{m}$, mucronate, with medium apex, hyaline in $\mathrm{KOH}$, thin-walls. Hymenophoral trama boletoid; hyphae gelatinized, cylindrical, 2-10 $\mu \mathrm{m}$ wide, hyaline in $\mathrm{KOH}$, pale brown in Meltzer, thin-walls. Pileipellis $105-120 \mu \mathrm{m}$ thick, composed of epicutis $32-104 \times 3.2-5.6 \mu \mathrm{m}$, subclavate, cylindrical with rounded apex, hyaline or pale brown in $\mathrm{KOH}$, brown in Meltzer, thin-walls. Stipitipellis 50-55 $\mu \mathrm{m}$ thick, formed by caulocystidia $12-48 \times 8-19.2 \mu \mathrm{m}$, cylindrical-clavate with thick-walls, hyaline in $\mathrm{KOH}$, with content in Meltzer.

Habitat - Solitary or dispersed, ectomycorrhizal with Quercus rugosa, Q. liebmanii and $Q$. scytophylla, from July to October, at 1400-2200 m.

Edibility - Edible

Known distribution - United States and Canada, Mexico (Bessette et al. 2000, 2017, García et al. 1998, García-Jiménez 1999, Garibay-Orijel et al. 2009).

Examined materials - MEXICO, OAXACA. District of Oaxaca de Juárez. Municipality of San Antonio de la Cal, West of the lake, 3 June 2014, Ayala-Vásquez, 354 (ENCB-ITCV), District of Villa de Zaachila, Municipality Santa Inés del Monte, June 2014, Ayala-Vásquez, 355 (ENCBITCV), District of Santiago Zacatepec Mixe. Municipalit Mixistlán de la Reforma, Santa María Mixistlán, west of the locality, 5 September 2015, Ayala-Vásquez 645 (ENCB), District Miahuatlán de Porfirio Díaz, Municipality San Mateo Río Hondo, J. Reyes S. 1825 (MEXU-2118), District Santiago Zacatepec Mixe. Municipality Mixistlán de la Reforma, Santa María Mixistlán, Ayala-Vásquez, 965 (ITCV).

Notes - Heimioporus betula is characterized by a viscid yellow to orange pileus, long stipe with a reticulate-alveolate ornamentation, basidiospores with superficial reticulum and scattered minute pits. The material described agree with the material by Singer (1945), Heim \& Perreau (1964).

Heimioporus ivoryi (Singer) E. Horak, Sydowia 56(2): 238 (2004).

Figs 12A-F, 14B-C

Pileus 50-76 mm diameter, convex when young, planate-convex when maturity, red (10A8, A10, 11A8, 11C8), violet brown (10E5), the surface dry, slightly furfuraceous to subtomentose, decurved margin, entire edge. Hymenophore subadnate, pores 1-1.4 mm diameter, hexagonal, yellow (30A8, 30B7), reddish brown (8D8) in maturity, tubes $9 \mathrm{~mm}$ length, concolored with the pores. Stipe $106 \times 8-20 \mathrm{~mm}$, clavate, surface of the apical and middle part reticulated, and furfuraceous at the base, apex yellow $(30 \mathrm{~A} 8,30 \mathrm{~B} 7)$, the remainder purplish violet-brown(10E5), brownish-red (9C8, 10A8, 10D8). Context $10 \mathrm{~mm}$ thick, yellow to light yellow, unchanging, in the maturity brownish-red $(9 \mathrm{C} 8,10 \mathrm{~A} 8,10 \mathrm{D} 8))$ in stipe context. Basal mycelium white.

Chemical reactions: when $\mathrm{KOH}$ is applied on the pileus context, the hymenophore and stipe turn reddish-brown (9D8, 9E8).

Basidiospores 15-16.5 (-18) $\times 7-8(-9) \mu \mathrm{m},(\mathrm{Q}=2.1, \mathrm{~N}=30)$, ellipsoid, with a reticulatealveolate ornamentation imbedded in a persistent, with suprahilar depression, yellowish brown in $\mathrm{KOH}$. Basidia 33-38×13-16 $\mu \mathrm{m}$, two-four spored, clavate-piriform, hyaline or olive-green in $\mathrm{KOH}$ with content in Meltzer. Pleurocystidia 23-30×9-14 $\mu \mathrm{m}$, clavate-mucronate or ventricose, with content, thin walls. Cheilocystidia 29-36 × 6-9 $\mu \mathrm{m}$, mucronate-rostrate, ampullaceous, with content, hyaline in $\mathrm{KOH}$, thin walls. Hymenophoral trama boletoid; hyphae gelatinized, cylindrical, 3-12 $\mu \mathrm{m}$ wide, hyaline in $\mathrm{KOH}$, brown in Meltzer, thin-walls. Pileipellis 200-250 $\mu \mathrm{m}$ thick, trichodermium, with terminal cells, 49-75 × 10-18 $\mu \mathrm{m}$, clavate-rostrate, hyaline in $\mathrm{KOH}$, with thick-walls. Stipitipellis 80-120 $\mu \mathrm{m}$ thick; caulocystidia 33-60 $\times 8-15 \mu \mathrm{m}$, clavate-rostrate, mucronate with content, thick-walls, hyaline in $\mathrm{KOH}$, without content in Meltzer.

Habitat - Solitary or scattered, growing in mulch of oak forest, associated forming ectomycorrhizas with Quercus scytophylla and Q. urbanii, at 1900-2350 m, from August-October. In Central America it is associated with Pinus caribea.

Known distribution- Belize and Mexico (Singer et al. 1992, García-Jiménez 1999, OrtizSantana et al. 2007). 
Examined materials- MEXICO, OAXACA, district Santiago Zacatepec Mixe. Municipality de Mixistlán de la Reforma, Santa María Mixistlán, 5 October 2014, Ayala-Vásquez 580 (ENCB, ITCV), District Santiago Zacatepec Mixe. Municipality Mixistlán de la Reforma, Santa María Mixistlán,4 August 2015, Ayala-Vásquez, 637,638 (ENCB-ITCV), district Santiago Zacatepec Mixe. Municipality Mixistlán de la Reforma, 14 June 2016, Ayala-Vásquez 643 (ITCV). District Santiago Zacatepec Mixe, Municipality San Pedro y San Pablo Ayutla, El Portillo to a altitud 2007m, 2 August 2016, Ayala-Vásquez, 661 (ITCV), District Zacatepec Mixe, Municipality Mixistlán de la Reforma, Santa María Mixistlán, N 1707’51.22” O 9605’16.97”, 6 June, 2017, Ayala-Vásquez 967 (ITCV).

Notes - Heimioporus ivoryi is characterized by its pink to reddish brown pileus, hymenophore invariably yellow, even when it is touched, the stipe is pink color with a yellow reticulum at the apex, the context invariably yellow, reddish brown when mature especially in the context of the stipe, and for its alveolate-reticulate basidiospores. The described material agrees with the description by García \& Castillo (1981) who cited it originally as Strobilomyces retisporus.

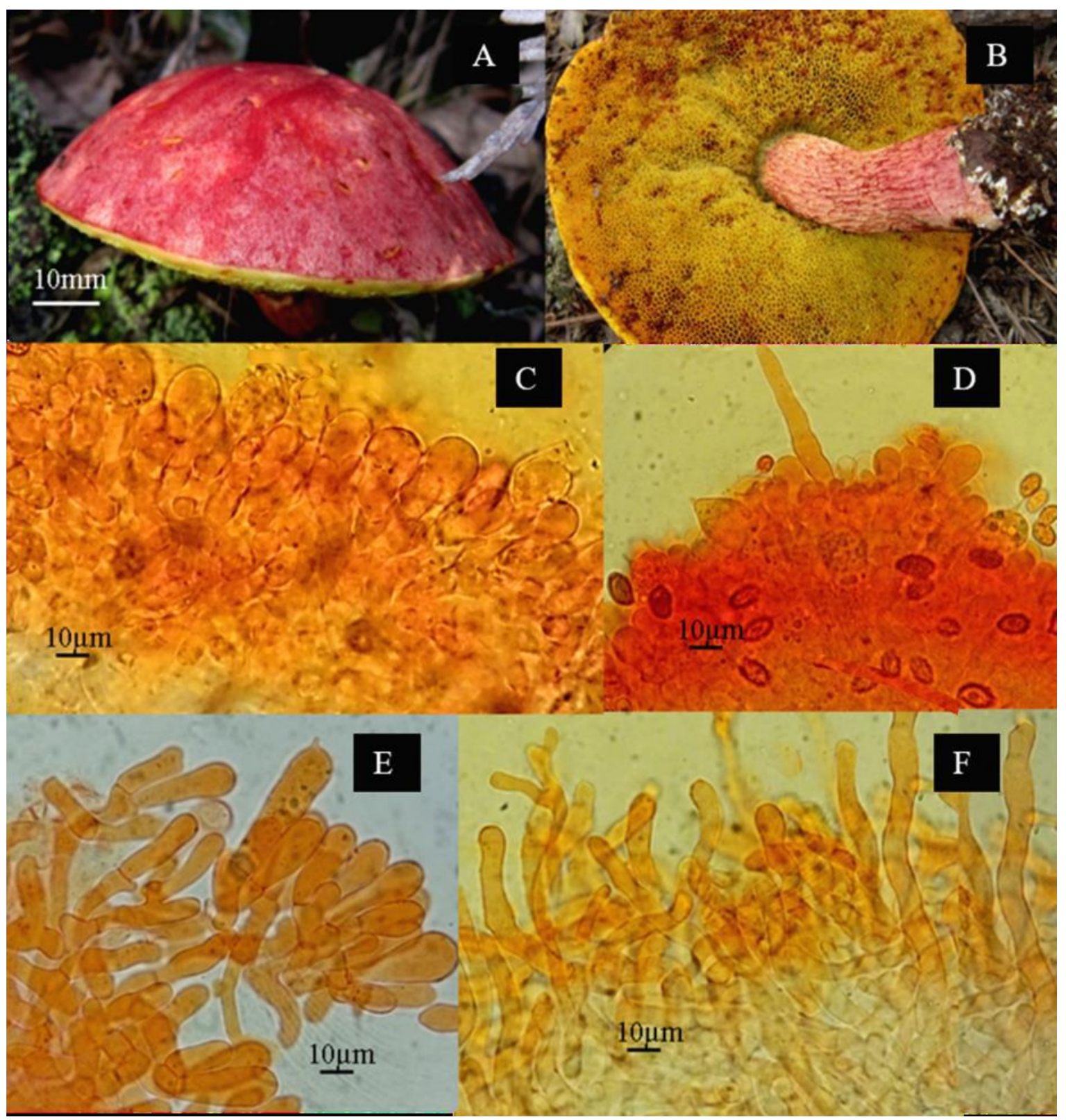

Fig. 12 - Heimioporus ivoryi (ITCV- 661). A- B Fresh basidiomata in the field. C Basidia and Pleurocystidia. D Cheilocystidia. E Caulocystidia. F Pileipellis. 
Pileus 50-80 $\mathrm{mm}$ diameter, convex when young, planate-convex when maturity, greyish white color, surface dry, squamose, cottony, areolate, completely covered by thin acute erect spines, dry surface, with prominent or appendiculate margin by the rests of a veil covering the hymenophore in its juvenile phases. Hymenophore depressed to subadnate, pores $1 \mathrm{~mm}$ diameter, circular, tubes $5 \mathrm{~mm}$ long, white-greyish becoming black when mature, when cut cinnamon and afterwards black. Context $10 \mathrm{~mm}$ thick, whitish to greyish, the cut turns reddish brown (8E8) the becoming black. Stipe $55-70 \times 7-20 \mathrm{~mm}$, clavate with bulbous base, surface furfuraceous to fibrillose, slightly reticulate at apex, light greyish brown with black fibrils.

Chemical reactions. When $\mathrm{KOH}$ is applied, the surface of the pileus changes to black, the context of the pileus turns yellowish brown, the hymenophore changes to dark brown (5F1) and the stipe to grayish-brown (6E3).

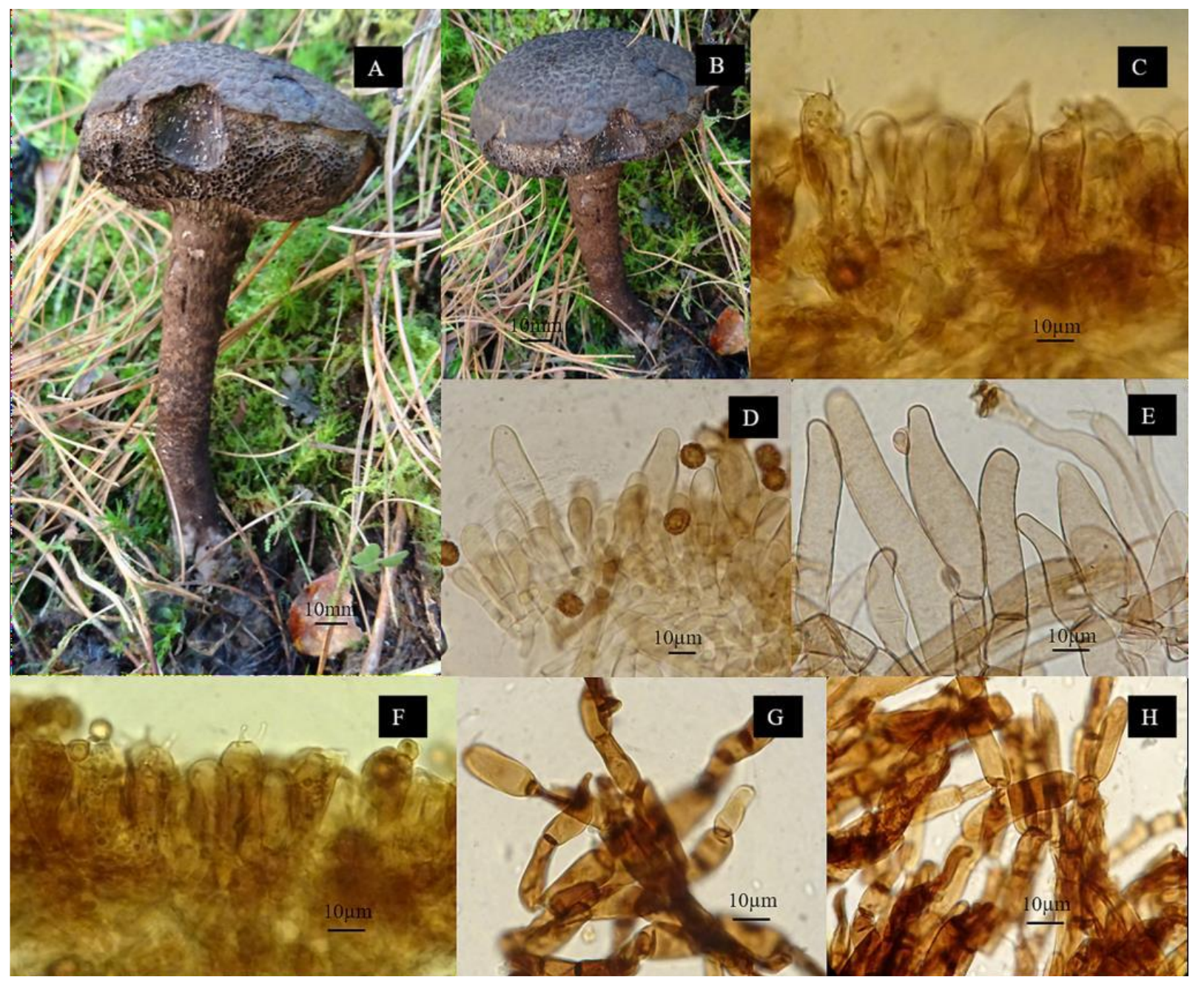

Fig. 13 - Strobilomyces confusus (ITCV- 1008). A-B Fresh basidiomata in the field. C Pleurocystidia. D Cheilocystidia. E Caulocystidia. F Basidia. G-H Pileipellis.

Basidiospores 10-12 × 8-10 $\mu \mathrm{m},(\mathrm{Q}=1.2, \mathrm{~N}=30)$, ellipsoid, subglobose, with verrucose or echinate ornamentations, brown color in $\mathrm{KOH}$ or Meltzer. Basidia 23-36 $\times 9-13 \mu \mathrm{m}$, clavate, fourspored, dark brown to hyaline in $\mathrm{KOH}$. Pleurocystidia 30-45 $\times 8-13 \mu \mathrm{m}$, fusiform-ventricose, mucronate, brown in $\mathrm{KOH}$. Cheilocystidia 29-35 $(-40) \times 8-12 \mu \mathrm{m}$, clavate, fusoid-ventricose with thick dark brown walls. Hymenophoral trama bilateral, interwoven with medium stratum composed by tubulose 3-8 $\mu \mathrm{m}$ diameter, lateral stratum whit tubulose hyphae 5-12 $\mu \mathrm{m}$, hyaline, brown in $\mathrm{KOH}$, thin-walled. Pileipellis formed by a trichodermium of cylindrical hyphae strongly interwoven 
with clavate terminations $39-86 \times 6-10 \mu \mathrm{m}$, hyaline in $\mathrm{KOH}$. Stipitipellis formed by caulocystidia $30-45 \times 10-15 \mu \mathrm{m}$, clavate, ventricose-rostrate, brown in $\mathrm{KOH}$.

Habitat - Solitary and disperse, forms ectomycorrhizas with $Q$. scytophylla, Q. martinezii from June to October at $2120-2700 \mathrm{~m}$. This species is very common in this type of vegetation and in pine-oak forests.

Edibility - Edible

Materials examined - MÈXICO, OAXACA. district Ixtlán de Juárez, Municipality Santa María Jaltianguis, Quercus forest, E. Pérez S. R. Hernández, E. Aguirre (MEXU-10512), District Santiago Zacatepec. Municipality of Mixistlán de la Reforma, Santa María Mixistlán, 27 July 2014, Ayala-Vásquez 407 (ENCB), District Santiago Zacatepec. Municipality of Mixistlán de la Reforma, Santa María Mixistlán locality, 1 August 2017, Ayala-Vásquez 942 (ITCV), Municipality Santa Catarina Ixtepeji, La Cumbre locality, 21 August 2017, Ayala-Vásquez 1008 (ITCV).

Known distribution- From Canada, United States, Colombia and Mexico (Heim \& Perreau 1964, Welden \& Guzmán 1978, García \&Castillo 1981, González-Velázquez \&Valenzuela 1993, GarcíaJiménez 1999, Garibay-Orijel et al. 2009).

Notes - Strobilomyces confusus is characterized by its hymenophore whitish to black gray, the context becomes red when bruised, basidiospores verrucose, brown-reddish. The described material agrees with the description by Heim \& Perreau (1964), García \& Castillo (1981) and García Jiménez (1999).

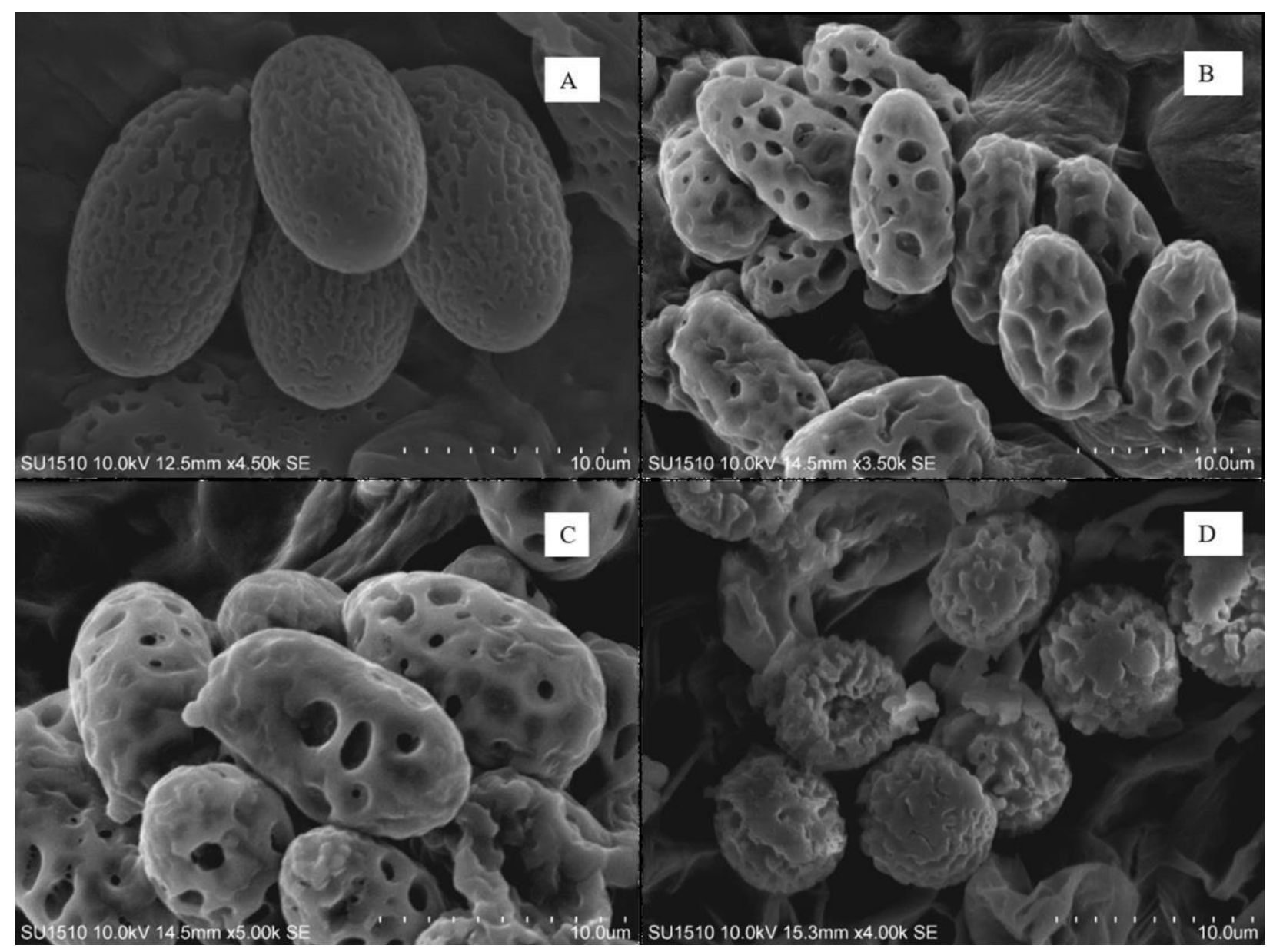

Fig. 14 - Ornamented basidiospores. A Heimioporus betula (ENCB-ITCV, 354). B-C Heimioporus ivoryi (ENCB- ITCV, 580). D Strobilomyces confusus (ENCB-407).

\section{Acknowledgements}

Ayala-Vásquez thanks CONACYT for financial support in postgrad and IPN for scholarship BEIFI. Valenzuela y Raymundo thanks to IPN for its financial support in the projects SIP20180243 
y SIP20180244. Community property curators are thanked for giving us access to their forests. Thanks to the M. In C. María Berenit Mendoza-Garfias, head of the laboratory of scanning electron microscopy, of the Instituto de Biologìa, UNAM. Thanks to M. Sc. de la Fuente for his comments and revision for the writing. García-Jiménez thanks PRODEP and general direction of Instituto Tecnológico de Ciudad Victoria, for supporting their research.

\section{References}

Bessette A, Roody WC, Bessette AR. 2000 - North American boletes: a color guide to the flesh and pored mushrooms. Syracuse University Press, New York. pp 396

Bessette A, Roody WC, Bessette AR. 2017 - North American boletes: a color guide to the flesh and pored mushrooms. Syracuse University Press, New York. pp 20-420.

Binder M, Hibbett DS. 2006 - Molecular systematics and biological diversification of Boletales. Mycologia 98: 971-983.

Centeno-García E. 2004 - Configuración geológica del estado. In: García-Mendoza AJ, Ordóñez MJ, Briones-Salas M, eds. Biodiversidad de Oaxaca. Mexico City: Universidad Nacional Autónoma de México, Fondo Oaxaqueño para la Conservación de la Naturaleza and WWF, $29-42$.

Cifuentes J, Villegas M, Pérez-Ramírez L, Sierra S. 1986 - Hongos. In: Lot, A., F. Chiang (eds.), Manual de Herbario. Administración y Manejo de Colecciones, Técnicas de Recolección y Preparación de Ejemplares Botánicos. UNAM-Consejo Nacional de la Flora de México, A.C., México. pp 55-64

Ferrusquía-Villafranca I. 1993 - Geology of Mexico: a synopsis. In: Ramamoorthy TP, Bye R, Lot A, Fa J, eds. Biological Diversity of Mexico: Origins and Distribution. New York: Oxford University Press, 3-107.

García J, Castillo J. 1981 - Las especies de Boletáceos y Gonfidiáceos conocidos en el Estado de Nuevo León. Boletín de la Sociedad Mexicana de Micología. 15: 121-197.

García, J, Pedraza D, Silva CI, Andrade RL, Castillo J. 1998 - Hongos del Estado de Querétaro. Hear Taller Gráfico, Santiago de Querétaro. pp 99-103.

García-Jiménez J. 1999 - Estudio sobre la taxonomía, ecología y distribución de algunos hongos de la Familia Boletaceae (Basidiomycetes, Agaricales) de México. Tesis de Maestria. Facultad de Ciencias Forestales. Universidad Autónoma de Nuevo León. pp 12-270.

García-Jiménez J, Garza-Ocañas F. 2001 - Conocimiento de los hongos de la familia Boletaceae de México. Ciencia UANL 4:336-343.

García-Jiménez J, Valenzuela R, Raymundo T, García Morales LJ et al. 2014 - Macrohongos asociados a encinares (Quercus spp.) en algunas localidades del estado del estado de Tamaulipas, México". Editores. A. Correa Sandoval, J. V. Horta Vega, J. García-Jiménez \& L. Barrientos Lozano. Biodiversidad Tamaulipeca. Vol 2. Num 1. Instituto Tecnológico de Ciudad Victoria, Tamaulipas, México.

García-Mendoza AJ, Ordóñez-Díaz MJ, Briones-Salas M. 2004 - Biodiversidad de Oaxaca. Editorial México: UNAM, Instituto de Biología. Pp 108-110.

Garibay-Orijel R, Martínez-Ramos M, Cifuentes J. 2009 - Disponibilidad de esporomas de hongos comestibles en los bosques de pino-encino de Ixtlán de Juárez, Oaxaca. Revista Mexicana de Biodiversidad. 80:2. 2009, pp. 521-534.

González-Velázquez A, Valenzuela R. 1993 - Los Boletáceos y Gomfidiáceos del Estado de México I. Revista Mexicana de Micología 9:35-46.

Grand LF, Moore RT. 1971 - Scanning electronic microscopy of basidiospores of species of Strobilomycetaceae. Canadian Journal of Botany. 49: 1259-1261.

Halling RE. 1997 - Boletaceae (Agaricales): Latitudinal biodiversity and biological interactions in Costa Rica and Colombia. Revista Biología Tropical. 44 (4): 111-114.

Halling ER, Nigel Fechner N, Nuhn M, Osmundson T et al. 2015 - Evolutionary relationships of Heimioporus and Boletellus (Boletales), with an emphasis on Australian taxa including new 
species and new combinations in Aureoboletus, Hemileccinum and Xerocomus. Australian Systematic Botany: 28 1-22. http://dx.doi.org/10.1071/SB14049

Heim R, Perreau J. 1964 - Les genres Porphyrellus et Strobilomyces au Mexique. Bulletin Société mycologique France. 80: 88-101.

Heinemann P, Goossens-Fontana M. 1954 - Flore iconographique des champignons du Congo. In: Fascicle 3. Boletineae. Brussels: Le jardín Botanique de l'Etat. p 51-78.

Horak E. 2004 - Heimioporus E. Horak gen. nov.: replacing Heimiella Boedijn (1951, syn. post., Boletales, Basidiomycota). Sydowia 56, 237-240

Hosen MI, Li TH. 2017 - Two new species of Phylloporus from Bangladesh with morphological and molecular evidence. Mycologia 109: 277-286. http://dx.doi.org/10.1080/00275514.2017.1312196

Jiménez-Ruiz M, Pérez-Moreno J, Almaraz-Suarez JJ, Torres-Aquino M. 2013 - Hongos silvestres con potencial nutricional, medicinal y biotecnológico comercializados en Valles Centrales, Oaxaca. Revista Mexicana Ciencia Agrícola.4. 2.199-213.

Kornerup A, Wanscher JH. 1978 - Methuen and book of colour, 31d ed. Eyre Methuen Ltd. London.

Lodge DJ, Ammirati JF, O`Dell TE, Müller G. 2004 - Collecting and describing macrofungi. In: Muller, G., Bills, G., Foster, M. (Eds.), Biodiversity of fungi inventory and monitoring methods. California: Elsevier Academic Press. P. 128-153.

Neves MA, Binder M, Halling RE, Soytong K. 2012 - The phylogeny of selected Phylloporus species, inferred from nrLSU and ITS sequences, and descriptions of new species from the Old World. Fungal Diversity 55: 109-123. http://dx.doi.org/10.1007/ s13225-012-0154-0.

Mueller MG, Halling ER. 1995 - Evidence for High Biodiversity of Agaricales (Fungi) in tropical Montane Quercus Forests. The New York Botanical Garden. pp 303-312

Murrill WA. 1949 - "Three New Fleshy Fungi." Mycologia 41(4): 490-491. Ortiz-Santana BD, Lodge DJ, Baroni TJ, Both EE. 2007 - Boletes from Belize and the Dominican Republic. Fungal Diversity 27: 247-416.

Paray L. 1951 - Exploraciones en la Sierra de Juárez. Boletín de la Sociedad Botánica de México 13: 4-10. DOI: 10.17129/botsci.973

Pegler DN, Young TWK. 1981 - A natural arrangement of the Boletales, with reference to spore morphology. Trans. Br. Mycol. Soc. 76: 103-146.

Rzedowski J. 1978 - Vegetaciòn de México, Ed. Limusa. Mex. 439pp.

Singer R. 1945 - The Boletineae of Florida with Notes on Extra limital Species I. The Strobilomycetaceae. Farlowia 2: 97-141.

Singer R. 1947 - The Boletoideae of Florida. The Boletineae of Florida with Notes on Extra limital Species III. American Mdland Naturalist37:1-135.

Singer R. 1955 - Type studies on Basidiomycetes. VIII. Sydowia 9: 367-431.

Singer R. 1970 - Strobilomycetacea (Basidiomycetes. Fl. Neotropic. 5, New York. Botanic Garden.

Singer R. 1986 - The Agaricales in Modern Taxonomy. 4a. Ed. Koeltz Scientific Books, Koenigstein. 981p.

Singer R, Araujo I, Ivory H. 1983 - The ectotrophycally mycorrhizal fungi of the Neotropical Lowland, especially Central Amazonia. Beihefte Zur Nova Hedwidgia 77:1-339.

Singer R, García-Jiménez J, Gómez LD. 1990 - The Boletineae of Mexico and Central America. III. Beih. Nova Hedwigia 98: 1-72.

Singer R, García-Jiménez J, Gómez LD. 1991 - The Boletineae of Mexico and Central America. III. Beih. Nova Hedwigia 102: 1-99.

Singer R, García-Jiménez J, Gómez LD. 1992 - The Boletineae of México and Central America. IV. Nova Hedwigia.105:1-62.

Smith AH, Thiers HD. 1971 - The Boletus de Michigan. The University of Michigan Press, Ann Arbor.

Snell WH. 1936 - Notes on boletes V. Mycologia 28:463-475.

Snell WH, Dick EA. 1970 - The bolete of north eastern North America. Cramer, Lehre. 
Tedersoo L, May TW, Smith ME. 2010 - Ectomycorrhizal lifestyle in fungi: global diversity, distribution, and evolution of phylogenetic lineages. Mycorrhiza. 20: 217-263.

Thiers HD. 1963 - The bolete flora of the Gulf Coastal Plain. I. The Strobilomycetaceae. Journal of the Elisha Mitchell Scientific Society: 79: 32-41.

Valencia AS. 2004 - Diversidad del género Quercus (Fagaceae) en México. Boletín de la Sociedad Botánica de México75: 33-53.

Welden AL, Guzmán G. 1978 - Lista preliminar de los hongos, líquenes y mixomicetos de las regiones de Uxpanapa, Coatzacoalcos, Los Tuxtlas, Papaloapan y Jalapa (parte de los estados de Veracruz y Oaxaca). Boletín de la Revista Mexicana de Micología 12: 5-12.

Wolfe CB. 1979 - Austroboletus and Tylopilus subg. Porphyrellus, with emphasis on North American taxa. Bibliotheca Mycologica. 69:1-148.

Wu G, Feng B, Xu J, Zhu XT et al. 2014 - Molecular phylogenetic analyses re-define seven major clades and reveal 22 new generic clades in the fungal family Boletaceae. Fungal Diversity 69: 93-115. http://dx.doi.org/10.1007/s13225-014-0283-8

Wu G, Li YC, Zhu XT, Zhao K et al. 2016 - One hundred noteworthy boletes from China. Fungal Diversity 81: 25-188. http://dx.doi.org/doi:10.1007/s13225-016-0375-8

Zeng NK, Tang LP, Li YC, Tolgor B, Zhu XT, Zhao Q, Yang ZL. 2013- The genus Phylloporus (Boletaceae, Boletales) from China: morphological and multi-locus DNA sequence analyses. Fungal Divers 58:73-101 